\title{
The Role of Ice-Sheet Topography in the Alpine Hydro-Climate at Glacial Times
}

\author{
Patricio Velasquez ${ }^{1,2}$, Martina Messmer ${ }^{1,2}$, and Christoph C. Raible ${ }^{1,2}$ \\ ${ }^{1}$ Climate and Environmental Physics, Physics Institute, University of Bern, Bern, Switzerland \\ ${ }^{2}$ Oeschger Center for Climate Change Research, University of Bern, Bern, Switzerland
}

Correspondence: Patricio Velasquez (patricio.velasquez@climate.unibe.ch)

\begin{abstract}
In this study, we investigate the sensitivity of the glacial Alpine hydro-climate to northern hemispheric and local ice-sheet changes. Bridging the scale gap by using a chain of global and regional climate models, we perform sensitivity simulations of up to $2 \mathrm{~km}$ horizontal resolution over the Alps for the Last Glacial Maximum (LGM) and the Marine Isotope Stage 4 (MIS4). In winter, we find wetter conditions in the southern part of the Alps during LGM compared to present day,

5 to which dynamical processes, i.e., changes in the wind speed and direction, substantially contribute. During summer, we find the expected drier conditions in most of the Alpine region during LGM, as thermodynamics suggests drier conditions under lower temperatures. The MIS4 climate shows enhanced winter precipitation compared to the LGM, which is explain by its warmer climate compared to the LGM - thus, again explained by thermodynamics. The sensitivity simulations of the northern hemispheric ice-sheet changes show that an increase of the ice-sheet thickness leads to a significant intensification of glacial Alpine hydro-climate conditions, which is mainly explained by dynamical processes. Changing only the Fennoscandian ice sheet is less influential on the Alpine precipitation, whereas modifications in the local Alpine ice-sheet topography significantly alter the Alpine precipitation, in particular we find a reduction of summer precipitation at the southern face of the Alps when lowering the Alpine ice sheet. The findings demonstrate that the northern hemispheric and local ice-sheet topography play an important role in regulating the Alpine hydro-climate and thus permits a better understanding of the precipitation patterns in
\end{abstract} the complex Alpine terrain at glacial times.

\section{Introduction}

Glacial times are characterised by very different boundary conditions than today, leading to cold conditions, substantial sealevel drops and a strong increase in land ice sheets (Mix et al., 2001). This different climate behaviour of glacial times have attracted the scientific community, since they are an ideal test bed to challenge state-of-the-art climate models in their ability to simulate changes in climate (e.g. Kageyama et al., 2021). Further, glacial times are also suitable to identify relevant mechanisms such as feedback processes in the climate system (e.g. Stocker and Johnsen, 2003) and to investigate response behaviour to external forcing (e.g. Ganopolski and Calov, 2011). Thereby, the hydrological cycle is an important ingredient in the Earth's climate system due to its transport and redistribution of mass and energy (e.g. Mayewski et al., 2004). To understand the climate during glacial times and to validate climate models proxy data are a prerequisite. Besides proxy data for atmospheric charac- 
https://doi.org/10.5194/cp-2021-67

Preprint. Discussion started: 21 June 2021

(c) Author(s) 2021. CC BY 4.0 License.
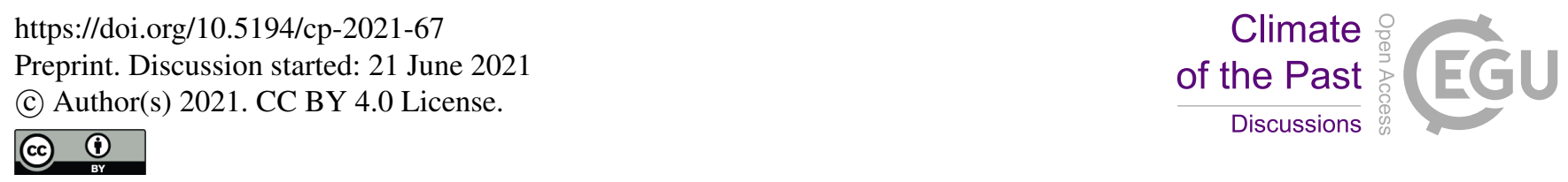

teristics, also the extent and height of the ice sheet must be known, since these have an influence on the atmospheric circulation (Monegato et al., 2017). Still, large uncertainties remain, in particular in land ice-sheet extent and height reconstructions prior to the Last Glacial Maximum (LGM, 21 ka; e.g. Peltier, 1994, 1998; Angelis and Kleman, 2005; Ehlers et al., 2011; Tarasov et al., 2012; Ullman et al., 2014; Batchelor et al., 2019; Gowan et al., 2021), but also the ice-sheet height during the LGM is still debated in literature (e.g. Peltier, 2004; Peltier et al., 2015; Ganopolski and Brovkin, 2017; Batchelor et al., 2019).

Thus, the purpose of this study is to investigate the role of the global and local ice-sheet topography in the regional hydroclimate over the European Alps with a focus on two glacial states, the LGM and the Marine Isotope Stage 4 (MIS4, 65 ka). In this study, we investigate to which extent changes in the dynamics are responsible for precipitation changes over the European Alps, based on eight high-resolution regional climate model (RCM) simulations.

So far, many proxy and global modelling studies have focused on the LGM (e.g. Yokoyama et al., 2000; Clark et al., 2009; Van Meerbeeck et al., 2009; Hughes et al., 2013) as LGM is also a focal period of the Paleoclimate Modelling Intercomparsion Projects (PMIP) (Abe-Ouchi et al., 2015; Kageyama et al., 2017). Globally, the reconstructed temperature at LGM is reduced by 5 to $6.5^{\circ} \mathrm{C}$ compared to present day (PD; Otto-Bliesner et al., 2006). This led to the building up of large ice sheets, in particular over the Northern Hemisphere (Peltier et al., 2015), a strong reduction in the sea level by approximately 115 to $130 \mathrm{~m}$ (Lambeck et al., 2014) and changes in vegetation and land surfaces (e.g. Annan and Hargreaves, 2013; Bartlein et al., 2011; Cleator et al., 2020), inducing higher atmospheric dust loadings during the LGM (Lambert et al., 2008). Paleoclimate reconstructions of Europe based on pollen data show, depending on the region, a temperature decrease of 10 to $14{ }^{\circ} \mathrm{C}$ (Wu et al., 2007; Bartlein et al., 2011). The same data is also used to reconstruct the hydro-climatic response over Europe at LGM showing mainly drier conditions (reduction in precipitation of around $200 \mathrm{~mm}^{-1} \mathrm{ar}^{-1}$ ) compared to PD (Wu et al., 2007; Bartlein et al., 2011). Other climate reconstructions suggest also circulation-induced changes in the moisture transport (Florineth and Schlüchter, 2000). In this case, the atmospheric circulation is changed so that the Alpine area receives more moisture from the south which results in wet conditions in the southern part of the Alps and dry conditions north of the Alps. This is confirmed by reconstructions based on speleothems in the Alpine region (Luetscher et al., 2015). Still, the interpretation of sparse paleo-proxy data remains a challenge due to the inherent uncertainties of proxy reconstructions, spatial coverage, uncertain seasonality of the proxy sensitivity, and contradicting signals recorded by different proxy archives (e.g. Wu et al., 2007; de Vernal et al., 2006; Beghin et al., 2016). MIS4 climate is less understood compared to LGM as proxy data availability is further reduced. Available paleoclimate reconstructions characterise MIS4 to be warmer than the LGM (e.g. Eggleston et al., 2016; Newnham et al., 2017; De Deckker et al., 2019) with a global sea level drop of roughly $80 \mathrm{~m}$ compared to PD (e.g. Cutler et al., 2003; Siddall et al., 2008, 2010; De Deckker et al., 2019).

Global climate model (GCM) simulations offer an alternative view on glacial climate conditions. With respect to the global mean climate response under LGM conditions, they are overall consistent with reconstructions (e.g. Braconnot et al., 2012; Hofer et al., 2012a; Kageyama et al., 2021). On the regional scale, GCM results show stronger deviations to reconstructions, e.g. they tend to underestimate the amplitude of European temperature between LGM and PD or partly disagree in the European precipitation pattern (Braconnot et al., 2012; Kageyama et al., 2017, 2021; Harrison et al., 2015). Besides, GCM simulations are used to deduce relevant processes and assess sensitivity of uncertain components, like the reconstruction of major ice-sheets 
(e.g. Angelis and Kleman, 2005; Tarasov et al., 2012; Ullman et al., 2014; Peltier et al., 2015; Batchelor et al., 2019). Several studies demonstrated a strong sensitivity of glacial climate to the extent and height of ice sheets (e.g. Kageyama and Valdes, 2000; Rivière et al., 2010; Hofer et al., 2012a, a; Merz et al., 2015). This is particularly true for the Laurentide ice sheet (LIS) as it drives major changes in the glacial atmospheric circulation and its variability compared to PD (Kageyama and Valdes, 2000; Rivière et al., 2010; Pausata et al., 2011; Hofer et al., 2012a; Merz et al., 2015; Harrison et al., 2016). For example, Hofer et al. (2012a) and Merz et al. (2015) found that an increase in the elevation of the LIS causes an enhancement and a southward displacement of the jet stream and the storm track over the North Atlantic. This has a strong impact on the precipitation pattern over Europe, in particular during winter. Still, GCMs operate on relatively coarse resolutions and thus poorly represent the effect of the topography at finer scales such as the complex Alpine terrain. Additionally, GCMs use parameterisations for processes that govern regional-to-local scale precipitation (Leung et al., 2003; Su et al., 2012).

Regional downscaling provides a way to overcome some of the shortcomings of GCM simulations. Latombe et al. (2018) proposed a statistical downscaling method to increase the spatial resolution of LGM simulations in a computationally efficient way. Another approach is dynamical downscaling by employing an RCM (e.g. Strandberg et al., 2011; Rummukainen, 2016; Ludwig et al., 2019). Among others, Ludwig et al. (2016) showed that the application of RCMs substantially improves the simulated LGM climate over Europe compared to the driving GCM, although biases from the GCM simulation may still impact the regional output. For instance, Ludwig et al. (2017) found that RCMs are sensitive to boundary conditions provided by GCM such as sea surface temperature. Thus, regional climate modelling is beneficial for answering paleoclimate research questions (Ludwig et al., 2019). Pinto and Ludwig (2020) and Raible et al. (2020) showed that extratropical cyclones are characterised by enhanced wind speeds over Europe during the LGM compared to PD, which helps to understand the reallocation and build-up of thick loess deposits in Europe (e.g. Römer et al., 2016; Krauß et al., 2016). Recently, the horizontal resolution of RCMs in the paleoclimate context is increased to a level that convection is explicitly resolved (e.g. Velasquez et al., 2020b). This study shows the benefit of higher spatial resolution in particular over areas with complex terrain such as the Alps. An accompanying study shows that also land surface conditions play an important role and need to be considered to realistically simulate the LGM climate state (Velasquez et al., 2020a), which is similar to earlier findings obtained with coarser resolved RCM simulations for LGM and MIS3 (Kjellström et al., 2010; Strandberg et al., 2011; Ludwig et al., 2017). Nevertheless, a detailed analysis of the sensitivity of the global and local ice-sheet topography on the regional hydro-climate over the European Alps — the purpose of this study — is missing. Hence, we employ eight high-resolution RCM simulations with the Weather Research and Forecasting (WRF) model (Skamarock and Klemp, 2008) driven by simulations under constant climate conditions using the Community Climate System Model version 4 (CCSM4, Gent et al., 2011). Thereby, we modify either the height of the northern hemispheric ice sheets, i.e. LIS, the Fennoscandian and Greenland ice-sheet in both CCSM4 and WRF, or the height of the Fennoscandian ice sheets (FIS) in the regional model or solely the height of the Alpine ice sheet in the regional model.

The study is structured as follows. Section 2 describes the models and experiments carried out in this study. Section 3 introduces methods used for analysing the role of the ice-sheet topography on the Alpine hydro-climate. In Sect. 4, we first characterise the two glacial states LGM and MIS4. Secondly, we investigate how the Alpine hydro-climate reacts to changes in 
https://doi.org/10.5194/cp-2021-67

Preprint. Discussion started: 21 June 2021

(c) Author(s) 2021. CC BY 4.0 License.

\section{(c) $\underset{\mathrm{BY}}{\mathrm{BV}}$}

Climate of the Past

Discussions

the northern hemispheric and the FIS, separately. In a third step, we assess the sensitivity of the Alpine hydro-climate to local

(Alpine) ice-sheet changes. Finally, a discussion and conclusive remarks are given in Sect. 5.

\section{Models and experiments}

The study is based on eight experiments using PD and glacial climate conditions to assess the role of the large-scale (LIS and FIS) and local (Alpine) ice-sheet topography on the Alpine climate. The focus on the European Alps necessitates to employ a model chain that consists of a GCM and RCM. Thereby, the GCM provides the initial and boundary conditions for the RCM. The models' configuration and the experiments are explained in the following.

The Community Climate System Model is used as GCM in the model chain (version 4, CCSM4; Gent et al., 2011). We use the atmosphere-land-only setting of CCSM4, i.e., the components of the atmosphere (CAM4, Neale et al., 2010) and land (CLM4, Oleson et al., 2010) are dynamical models whereas the ocean and sea ice components are so-called data models obtained from a coarsely resolved fully coupled simulation performed with CCSM3 (Hofer et al., 2012a). Thus, the two data models force the atmospheric component by time-varying sea-surface temperatures and sea-ice cover. The atmosphere-landonly model is run for 33 years with 6-hourly output, a horizontal resolution of $1.25^{\circ} \times 0.9^{\circ}$ (longitude $\times$ latitude) and 26 vertical hybrid sigma-pressure levels in the atmosphere and 15 layers in the land component. In this study, we use the first 21 or 12 years of the GCM simulation that follow after the first 3 years of spin-up.

Five global climate simulations provide the RCM with initial and boundary conditions. Two of these CCSM4 simulations are performed under PD 1990 CE conditions and LGM conditions, respectively. The other three simulations are performed under MIS4 conditions. The orbital forcing and atmospheric composition are adjusted to the respective period (Table 1). The MIS4 simulations differ in their northern hemispheric ice-sheet elevation: 66, 100 and 125\% of the LGM ice-sheet elevation, respectively. Note that glaciers and small ice caps such as the ones over the Alps and Pyrenees are not included in these simulations due to the coarse resolution of approximately $100 \mathrm{~km}$ in the GCM. More detailed information on these simulations and their settings are presented in Hofer et al. (2012a, b) and Merz et al. (2013, 2014a, b, 2015).

The global CCSM4 simulations are dynamically downscaled with the RCM Weather Research and Forecasting (WRF) model (version 3.8.1, Skamarock et al., 2008). This RCM solves the basic non-hydrostatic equations with an Eulerian mass-coordinate solver and employs a terrain-following eta-coordinate system in the vertical. We use an adaptive time-step, 40 vertical eta levels and four domains that are two-way nested. The horizontal resolution of these four domains is 54, 18, 6 and $2 \mathrm{~km}$, respectively. The domains focus on the Alpine region; the outermost domain includes Europe and part of the North Atlantic to capture the influence of the North Atlantic Ocean and the FIS on the European climate (Fig. 1). Furthermore, we use the same setting as in Velasquez et al. (2020b), thus we refer to this publication on the details of the relevant parameterisation schemes used. Still, we highlight that the horizontal resolutions in the two innermost domains ( 6 and $2 \mathrm{~km}$ ) are convection permitting, i.e., we omit the use of parameterisation for convection in these two domains. WRF uses 21 or 12 years (compare Table 2 for more details) of the corresponding GCM simulation as initial and boundary conditions, but WRF is not nudged to the GCM output. These 21 and 12 years are further split up into 7 and 4 individual 3-year simulation segments, respectively, to efficiently use 
https://doi.org/10.5194/cp-2021-67

Preprint. Discussion started: 21 June 2021

(c) Author(s) 2021. CC BY 4.0 License.

\section{(c) (i)}

the available computer facilities. For each segment, a 2-month spin-up is needed in order to allow the land surface to come into quasi-equilibrium. Tests suggest that a 2-month spin-up is sufficient to obtain a quasi-equilibrium of the upper meter of the land surface (Velasquez et al., 2020b, a).

The first experiment ( $\mathrm{PD}_{\mathrm{PD}}$ ) is a reference simulation under PD conditions (1990 CE conditions). We run WRF for 21 years using $1990 \mathrm{CE}$ conditions and initial and boundary conditions of the corresponding CCSM4 simulation (Table 1). PDPD uses the default PD MODIS-based land cover dataset from WRF as land surface boundary conditions (Skamarock et al., 2008).

The second experiment $\left(\mathrm{LGM}_{\mathrm{LGM}}\right)$ uses the external forcing of the LGM (Table 1), except for eccentricity and precession. The reason is that in the radiative routine of WRF only the obliquity parameter is processed. We realised this problem after the simulations have been performed. We expect that this problem is of minor importance as the driving CCSM4 uses all orbital parameters and thus the orbital signal is at least partly included in the simulations. Some preliminary results with a model version, which fixes this bug, shows no strong dependence on this error under LGM conditions (Emmanuele Russo pers. comm.). Additionally, the $\mathrm{LGM}_{\mathrm{LGM}}$ surface conditions need some further adjustments. These include the lowering of the sea level and ice sheets as specified in the PMIP3 protocol (Fig. 1b; for more details see: Ludwig et al., 2017). The glaciation over the Alpine region (obtained from Seguinot et al., 2018) and other glaciated areas (e.g. Pyrenees, from Ehlers et al., 2011) are modified according to LGM conditions (Fig. 1b). Additionally, the land cover is altered to comply with LGM conditions, as described in Velasquez et al. (2020a). Comparing LGM $_{\mathrm{LGM}}$ with $\mathrm{PD}_{\mathrm{PD}}$ illustrates the entire effect of changes in the external forcing and in the surface conditions (sea level drop, land cover and northern hemispheric ice sheets). Note that the LGM $_{\mathrm{LGM}}$ simulation is evaluated against proxy evidence (Prentice and Jolly, 2000; Wu et al., 2007; Kaplan et al., 2016) showing an improved LGM climate state in the WRF simulation (Velasquez et al., 2020b, a) compared to the driving CCSM4 simulations (Hofer et al., 2012a).

The third to seventh experiments assess the sensitivity of the Alpine climate to changes in the northern hemispheric ice-sheet configuration. Thereby, the MIS4 simulations of CCSM4 are dynamically downscaled with WRF resulting in MIS4 $4_{\text {LGM66 }}$, MIS4 $4_{\text {LGM }}$ and MIS4 $4_{\text {LGM125. }}$. These three WRF simulations are run for 21 years using MIS4 conditions and using the LGM $_{\text {LGM }}$ land cover (described in Velasquez et al., 2020a). Note further that the Alpine ice sheet is always set to LGM conditions (Fig. 2b). Following their driving CCSM4 simulations, we perform each WRF simulation with a different Fennoscandian ice-sheet thickness: 66, 100 and $125 \%$ of the LGM ice-sheet thickness, respectively. MIS4 $4_{\text {LGM }}$ serves as reference for MIS4 $4_{\text {LGM66 }}$ and MIS4 $4_{\text {LGM125 }}$.

To investigate the effect of the FIS on the Alpine climate, we perform two additional sensitivity simulations: LGM FIS50 $_{\text {and }}$

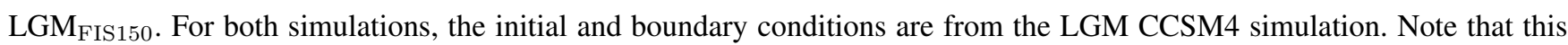
CCSM4 simulation uses $100 \%$ LGM ice-sheet configurations. To assess the influence of the FIS, we reduce or increase FIS thickness to $50 \%$ and $150 \%$, but only in the WRF model. Both simulations are run for 12 years.

With the eighth experiment, we investigate the influence of local modifications of the Alpine ice sheet on the Alpine climate.

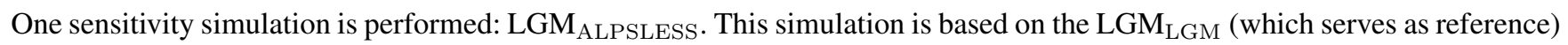
but with a modified Alpine topography (Fig. 2c). LGM $_{\text {ALPSLESS }}$ is run for 21 years and with a reduced Alpine glacier thickness. 
This reduction becomes stronger with height; namely, the Alpine ice sheet is strongly reduced over mountain peaks and slightly over the low lands. All eight experiments are summarised in Table 2.

\section{Methods}

The analysis of the past hydro-climate and its response to different forcing factors is based on climatological means of precipitation, their differences between the experiments and some of the driving factors for these differences, e.g. changes in humidity or wind. We assess the statistical significance with a bootstrapping technique (Wilks, 2011). This technique randomly selects elements from the original sample to generate a new sample, also called resampling, whereby the number of elements remains unchanged. This procedure is repeated 1000 times. A new mean value is calculated from each resampling leading to 1000 mean values that are used to build a probabilistic distribution function (PDF). We assess the significance of the mean value using a significance level of 0.05 (0.025 for each PDF's tail). The bootstrapping technique is applied at each grid point using as elements the 30 annual mean values.

Additionally, we analyse vertical atmospheric profiles using the SkewT-Log P diagram (AWC, 1969, 1990; NOAA, 2021) to gain insights into the atmospheric drivers of precipitation changes. The SkewT-LogP or Skew-T diagram is a thermodynamic diagram that is widely used in atmospheric science, particularly by meteorologists for weather forecasts (e.g. Duarte and Gomes, 2017; Morsy et al., 2017; da Silva et al., 2019; Chen et al., 2020). It illustrates the vertical atmospheric state by several meteorological variables such as air temperature, humidity, wind speed and wind direction. The $x$-axis indicates temperature and the $y$-axis pressure levels in a logarithmic scale (thus the name $\operatorname{LogP}$ ). There are usually five isolines on the diagram: isotherms, isohumes (or mixing ratio lines), dry adiabatic lines (or lines of equal potential temperature $\theta$ ), isobars, and moist adiabatic lines. In this study, we use a simplified diagram that only contains the first three variables for the analysis as we focus on changes in temperature, humidity and wind. For instance, an unsaturated air panel follows a dry adiabatic line when ascending without changes of state, i.e., there is no loss or gain of latent heat. These lines are used in this study to qualitatively estimate the stability of the atmosphere. A stable atmosphere is characterised by an increase of potential temperature with height.

Two vertical profiles are included in the Skew-T diagram: temperature (solid lines) and dew-point temperatures (dashed lines). The latter simply indicate temperatures at which the air becomes saturated and is used to deduce the mixing ratio with height, i.e., the amount of water vapour in the air where the dew point temperature line crosses the mixing ratio line. Both temperatures are used to investigate the relative humidity, i.e., the level of saturation at a certain pressure and temperature. This is done by qualitatively estimating the distance between both temperatures. A short distance indicates a high relative humidity and, inversely, a large distance a low relative humidity. Wind speed and direction are illustrated by wind bars in $\mathrm{km} \mathrm{h}^{-1}$.

The Skew-T diagram is built with climatological means of the atmospheric variables above surface at the following pressure levels: 1000, 925, 900, 850, 800, 750, 700, 600, 500, 400, 300, 250, 200 and $100 \mathrm{hPa}$. We consider the lowest pressure level above surface as the best representation of the near-surface atmosphere. Two additional vertically integrated quantities are given at the top of the diagram: precipitable water (PW) and convective available potential energy (CAPE). CAPE quantita- 
https://doi.org/10.5194/cp-2021-67

Preprint. Discussion started: 21 June 2021

(c) Author(s) 2021. CC BY 4.0 License.

\section{(c) (i)}

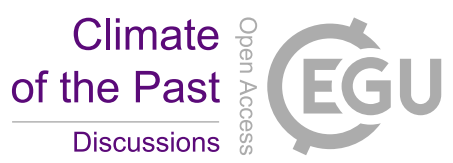

tively represents the energy available for convective processes, the higher it is the stronger these processes could be (for more information see chapter 8 of Wallace and Hobbs, 2006). In this study, we use the climatological mean values to calculate the PW and CAPE values; the later are only shown at the top of the diagram when it is different from zero.

\section{Results}

In the following, the glacial Alpine hydro-climate is characterised for two glacial states the LGM and MIS4. Then, we investigate the sensitivity of the hydro-climate to northern hemispheric ice-sheet changes for MIS4 and the sensitivity to the FIS for LGM. We assess the Alpine hydro-climate response to changes in the Alpine ice sheet by one simulation using LGM conditions. For the analysis, we select winter (DJF, December-January-February) and summer (JJA, June-July-August) as these two seasons summarise the changes in spatial precipitation patterns over the Alpine region. The other two transition seasons (MAM, March-April-May and SON, September-October-November) show either similarities to winter (for MAM) or summer (for SON). The analysis is based on the innermost domain of the WRF simulations (Fig. 2).

\subsection{Characterisation of the glacial hydro-climate of the Alps}

Present-day hydro-climate over the Alpine area is characterised by the large scale atmospheric circulation with its dominant westerlies, influences from the Mediterranean (Messmer et al., 2015, 2017, 2020) and convective processes (Ban et al., 2014; Gómez-Navarro et al., 2018). In winter, the westerlies are enhanced, so that we observe high precipitation amounts in the north-western area of the domain and at the northern face of the Alps, whereas the southern and the eastern parts receive less precipitation (Fig. 3a). Due to the orographic barrier of the Alps the flow is uplifted leading to a higher precipitation intensity over mountain tops and lower intensity in valleys. In summer, the precipitation pattern is more uniform over the Alps, showing high intensities also on the southern face of the Alps and in the east (Fig. 3e). This suggests that the topographically triggered convection is an important process in summer under PD climate.

The LGM shows a completely different precipitation behaviour over the Alps (Fig. 3). In winter, precipitation is mostly concentrated on the south-western Alps (Fig. $3 \mathrm{~b}$ and c) with a statistically significant increase of more than $8 \mathrm{~mm}^{-1} \mathrm{y}^{-1}$ compared $^{-}$ to PD (Fig. 3c). The southern face of the Alps generally shows a statistically significant increase of winter precipitation of about $3 \mathrm{~mm}$ day $^{-1}$ during LGM compared to PD, whereas the northern face experiences a statistically significant decrease of more than $6 \mathrm{~mm} \mathrm{day}^{-1}$ (Fig. 3c). During summer, precipitation is significantly reduced at LGM compared to PD (Fig. 3e, f and $\mathrm{g}$ ), which suggests that convective processes, typically observed in PD summer, are less active during the LGM. Still, few areas show wetter conditions during the LGM compared to PD, particularly over mountains peaks in the western Alps (Fig. $3 \mathrm{~g}$ ). The increase in precipitation observed over mountain peaks indicates precipitation induced by orographic lifting. As the surroundings are drier it is assumed that the higher elevation of the Alps during LGM triggers precipitation only at the highest points.

To further understand the precipitation changes between LGM and PD, we use the Skew-T diagram, as introduced in Sect. 3.

The vertical profiles are estimated for two sites: upstream to the Alpine region (site A, north-western region) and downstream 
https://doi.org/10.5194/cp-2021-67

Preprint. Discussion started: 21 June 2021

(c) Author(s) 2021. CC BY 4.0 License.
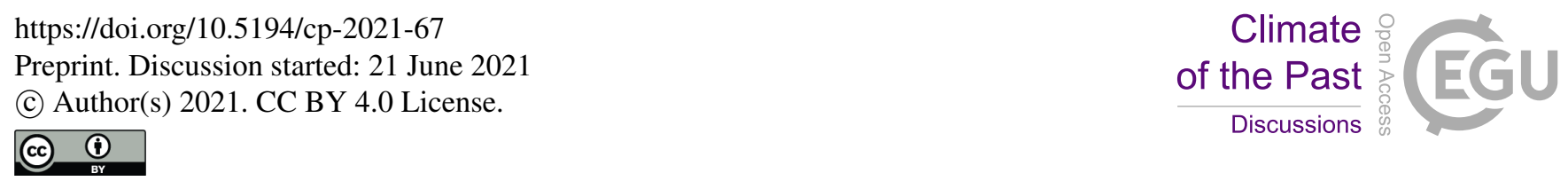

(site B, central-southern region) according to the general westerlies of the mid latitudes (Fig. 2). Note that these two sites are over rather flat terrain and therefore experience less influence from local orographic-induced atmospheric dynamics such as the mountain-valley breeze.

Starting with the Skew-T diagrams in winter (Fig. 4a and c), we find the expected strong reduction of LGM temperatures compared to PD at both sites. The mixing ratios are also reduced in the LGM compared to PD resulting in less precipitable water under LGM conditions at both sites. Interestingly, the relative humidity, measured by the distance between dew-point temperature and temperature remains unchanged when comparing LGM and PD. However, we find a clear structural change in the vertical profiles of the temperatures, as illustrated by the different slopes between LGM and PD. Both sites show that potential temperature values (comparing the temperature profile with the dashed brown lines) overall increase with height indicating a stable atmosphere. This increase is stronger in the LGM indicating a more stable atmosphere at both sites compared to PD. Particularly, the stability is higher in site A (north-western part) than in site B (central-southern region) in winter, which is a first hint that both regions show different behaviours in their winter precipitation. Another hint is given by the wind speed and direction, since we find an increase in wind speed and an anticlockwise rotation of the LGM compared to PD. This is evident at both sites but the rotation is more pronounced in the central-southern region. The boundary layer is thicker in the LGM than in PD, in particular for the central-southern region. Both sites show the expected lowering of the tropopause during the LGM due to colder conditions compared to PD.

Summer shows a rather similar behaviour as winter, but with a few exceptions related with the season (Fig. $4 \mathrm{~b}$ and d). CAPE is only observed during PD summer at both sites. Additionally, we find a development of a small boundary layer under LGM conditions, which is not present under PD conditions. Furthermore, the wind is rotated slightly clockwise at site A (northwestern region), whereas site B (central-southern region) shows an anticlockwise rotation. Again, at both sites, the wind speed is increased in the LGM, but not as clearly as in winter.

To gain further insights in the advection of moisture, we exhibit the wind vectors at $700 \mathrm{hPa}$. This level summarises winds in the low-to-mid troposphere. Note that this pressure level could also represent near-surface winds over mountain peaks in certain regions. Compared to PD wind vectors, LGM winds are significantly stronger and rotated anticlockwise during winter (Fig. 5a), confirming the finding of the Skew-T diagrams (Fig. 4 a and c). Almost the entire domain shows significant changes in both wind components (red shading in Fig. 5a). Stronger winds are also observed during summer but with slightly different rotation patterns across the domain (Fig. 5c). These winds are generally rotated anticlockwise except for the southwestern region of the domain where it is clockwise. The increase in speed covers approximately half of the domain, which is attributed to either significant changes in the zonal component (U) only or both wind components (i.e., blue or red shading, respectively; Fig. 5c). Similarly, the wind rotation also covers about half of the domain, which is associated to either significant changes in the meridional component $(\mathrm{V})$ only or both wind components (i.e., areas in grey or red, respectively; Fig. 5c).

MIS4 is the second glacial state considered here. Figure 3d shows that winter precipitation intensities of MIS4 $4_{\text {LGM }}$ are higher than LGM ones, especially over some areas such as the western area of the domain with a significant increase of about $3 \mathrm{~mm}_{\text {day }}{ }^{-1}$. This is expected as MIS4 ${ }_{\text {LGM }}$ climate is warmer than LGM, thus the ability of the atmosphere to hold more moisture is increased due to the Clausius-Clapeyron equation (e.g. third chapter of Wallace and Hobbs, 2006). In summer, the 
https://doi.org/10.5194/cp-2021-67

Preprint. Discussion started: 21 June 2021

(c) Author(s) 2021. CC BY 4.0 License.

precipitation difference between MIS4 and LGM shows a significant north-south dipole pattern (Fig. 3h). There are slightly wetter conditions of about $1.5 \mathrm{~mm}_{\text {day }}{ }^{-1}$ on the northern face of the Alps during MIS4 $4_{\text {LGM }}$ compared to LGM. On the southern face of the Alps precipitation is reduced by around $2 \mathrm{~mm} \mathrm{day}^{-1}$.

To understand these differences, we again investigate the atmospheric vertical profiles at both sites. Overall, the MIS4 profiles look very similar to LGM ones during winter. The expected shift towards warmer conditions under MIS4 conditions is visible at both sites (Fig. 4a and c), in particular in the lower part of the troposphere (mainly in the boundary layer), leading to higher mixing ratios in MIS4 compared to LGM. The comparison of MIS4 and LGM further shows that the stability is slightly reduced under MIS4 conditions in the lower part of the troposphere (up to $600 \mathrm{hPa}$; Fig. 4a). This reduction is more evident in the north-western region (site A), whereas the stability in the central-southern region (site B) is slightly reduced in the mid layer of the troposphere (between 800 and $400 \mathrm{hPa}$; Fig. 4c). The wind directions seem to be unchanged with slightly lower wind speeds under MIS4 than LGM conditions. Thus, thermodynamic changes are the major processes in explaining the increased winter precipitation during MIS4 (Fig. 3d). In summer, the temperature profiles agree between the two glacial states at both sites, except for a shift towards higher temperatures leading again to higher mixing ratios. The only deviation is that the boundary layer shows a slightly stronger inversion during MIS4 than LGM at both sites. The shift to warmer temperature and higher mixing ratios suggest a general moistening under MIS4 compared to LGM conditions, which can explain the increase in summer precipitation in the northern part but not the decrease in the southern part of the domain.

Therefore, we assess the wind fields in more detail. Figure 5b shows that MIS4 winds become weaker during winter compared to LGM, but a rotation is almost absent. During summer, MIS4 winds become stronger with a slight clockwise rotation compared to LGM (Fig. 5d). Both, the increase in speed and the rotation, enhances the wind shear in the low-to-mid troposphere (Fig. 4) resulting in more convective-related precipitation in the northern part of the Alps, whereas the clockwise rotation over the southern face of the Alps in MIS4 leads to reduced moisture availability as the flow dries out when crossing the Alps and reaching the Po valley (Foehn process).

In summary, we find that both thermodynamic and dynamical changes are responsible to generate precipitation changes in winter and summer when comparing LGM and PD conditions and MIS4 and LGM, respectively. Interestingly, the changes in winter precipitation between LGM and PD is explained by a combination of thermodynamic and dynamic processes, whereas the summer reduction is mainly explained by thermodynamics and reduced convection. The comparison of MIS4 and LGM shows that the winter changes are mainly driven by thermodynamics, whereas in summer also dynamical changes are important.

\subsection{Sensitivity of the Alpine hydro-climate to northern hemispheric ice-sheet changes}

Here, we investigate the role of the northern hemispheric ice-sheet topography in the Alpine climate. Two sets of sensitivity simulations are used. The uncertainty in the thickness of the northern hemispheric ice sheets is assessed by comparing two simulations with 66 and $125 \%$ to the one with $100 \%$ LGM ice-sheet thickness under MIS4 conditions. The second set of simulations uses the LGM climate state as a reference and only the FIS thickness is changed by 50 and $150 \%$.

We first focus on the precipitation response to these changes in ice-sheet thickness. The comparison of MIS4 ${ }_{\text {LGM66 }}$ with MIS4 $_{L G M}$ shows that lowering the northern hemispheric ice sheets by $66 \%$ significantly increases the winter precipitation by 
about $3 \mathrm{~mm}$ day $^{-1}$ on the northern face of the Alps and leads to significantly drier conditions in the rest of the domain (Fig. 6b). In particular, winter precipitation is reduced by up to $8 \mathrm{~mm} \mathrm{day}^{-1}$ in the south-western Alps (Fig. 6b). Comparing these patterns to the difference between PD and LGM, we find a north-south winter pattern inversely to the one of PD and LGM. This suggests that decreasing ice-sheet thickness (i.e., MIS4 $4_{\text {LM } 66}$ ) leads to more PD-like conditions during glacial climates. Summer precipitation differences between the two experiments resembles the winter pattern, but the amplitudes are reduced, i.e., precipitation is increased by about $2 \mathrm{~mm} \mathrm{day}^{-1}$ on the northern face of the Alps and reduced by about $1 \mathrm{~mm} \mathrm{day}^{-1}$ in the western part of the domain (Fig. 6e). The southern part shows no significant changes. This pattern of precipitation is only partly similar to the difference pattern of the LGM and PD.

An increased ice-sheet thickness as in MIS4 $4_{\text {LGM125 }}$ shows a different influence on precipitation patterns (Fig. $6 \mathrm{c}$ and f). In winter, the difference pattern in precipitation between MIS4 $4_{\text {LGM125 }}$ and MIS4 $_{\text {LGM }}$ is similar to the one found between LGM and MIS4 $4_{\text {LGM }}$ with overall wetter conditions. Especially, we find significantly high precipitation intensities up to $3 \mathrm{~mm}$ day $^{-1}$ on the north western and southern regions of the domain (Fig. 6c). The northern face of the Alps shows a decrease in the precipitation intensities. Thus, we interpret that the response of winter precipitation is linear with respect to the northern hemispheric ice-sheet thickness changes. In summer, we generally find drier conditions in the MIS4 $4_{\text {LGM125 }}$ than in MIS4 $4_{\text {LGM }}$, in particular significantly lower precipitation of up to $-3 \mathrm{~mm} \mathrm{day}^{-1}$ on the central to southern part of the domain (Fig. 6f). This indicates that increasing northern hemispheric ice-sheet thickness (such as in MIS4 $4_{\text {LGM125 }}$ ) enhances glacial climate conditions.

Secondly, we focus on the other set of sensitivity simulations under LGM conditions, where only the FIS thickness is varied. These simulations show a rather weak response of the precipitation within the domain (Fig. 7). In winter, increasing or decreasing the FIS thickness does not lead to significant changes in precipitation (Fig. 7a and b). In summer, we find an increase in the southern part of the domain for both sensitivity simulations (Fig. $7 \mathrm{c}$ and d) and a small but significant increase in the northeast of the domain in the LGM $\mathrm{FIS} 150_{0}$ simulation.

Again, the Skew-T diagram is used to understand the role of the vertical behaviour of the atmosphere on precipitation changes at the two sites (Fig. 2). The sensitivity simulations of the northern hemispheric ice-sheet height shows that at both sites the wind speed in winter is enhanced and anticlockwise rotated with increasing ice-sheet thickness (Fig. 8a and c). While decreasing northern hemispheric ice-sheet thickness leads to slightly weaker and clockwise rotated winds and a slightly warmer atmosphere. The latter results in a small increase of moisture availability (dashed green lines), especially in the central-southern region (site B) where there is more precipitable water (Fig. 8a and c). In summer, only small wind changes are found at both sites (Fig. 8b and d) and changes in the other variables of the Skew-T diagram are mainly restricted to the lower troposphere and the boundary layer (Fig. 8b and d). We find a reduced relative humidity at site A (north-western region), measured by the distance between the dew-point temperature and temperature, and lower mixing ratios (dashed green lines) at site B (centralsouthern region) with increasing ice-sheet thickness. This suggests dryer conditions at both sites in the case of MIS4 LGM125. The Skew-T diagrams for the sensitivity of the FIS do not show strong differences (therefore not shown). Thus, the Skew-T analysis confirms that an increase in northern hemispheric ice-sheet thickness enhances glacial climate conditions. It further 
suggests that similar processes as discussed in the comparison between LGM and PD are responsible for precipitation changes, whereas only changing the FIS does not seem to have strong implications.

The Skew-T diagrams already give some hints to wind alterations with respect to changes in the northern hemispheric ice-sheet topography. Thus, we further assess the role of the northern hemispheric ice-sheet topography on the Alpine winds by showing the $700 \mathrm{hPa}$ wind fields. In general, we observe that wind speed is weaker with decreasing ice-sheet thickness. In winter, we find a clockwise rotation of the wind vectors over the entire domain with decreasing northern hemispheric icesheet thickness (Fig. 9a and b). These modifications are generally associated with either significant changes in the meridional component (V) only or both wind components (i.e., grey or red shading, respectively; Fig. 9a and b). In summer, we find that winds rotate clockwise with decreasing ice-sheet height (Fig. $9 \mathrm{c}$ and d). The alterations in summer are related to either significant changes in the zonal and meridional component ( $\mathrm{U}$ and $\mathrm{V}$ ) only or both wind components (i.e., blue, grey or red shading, respectively; Fig. 9c and d). Thus, the winter and summer wind fields react similar to the comparison between LGM and PD suggesting that northern hemispheric ice-sheet thickness is an important driver of the advection processes over the Alps. Again, the sensitivity simulations with changed FIS thickness do not show significant changes in the wind field (therefore not shown), which again confirms the findings that the thickness of the FIS seems to have limited influence on Alpine precipitation.

In summary, the analysis shows that winter and summer seasons react differently to northern hemispheric ice-sheet thickness changes, but resemble the processes already found in the comparison between LGM and PD: Increasing northern hemispheric ice-sheet thickness generally leads to enhanced glacial conditions, i.e., a moistening during winter due to dynamic processes and a drying in summer mainly explained by thermodynamics. The sensitivity of precipitation to the FIS thickness is rather weak and the simulations suggest that its thickness has only a negligible influence on the Alpine precipitation.

\subsection{Sensitivity of the Alpine hydro-climate to Alpine ice-sheet changes}

Besides changes in the northern hemispheric ice sheet, modifications in the Alpine ice sheet might also influence Alpine

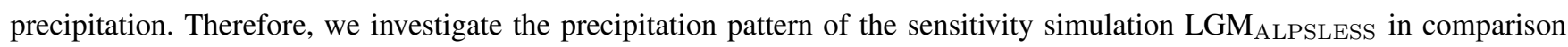
to $\mathrm{LGM}_{\mathrm{LGM}}$. Then, we assess the processes explaining these changes using again the Skew-T diagram and the wind field at $700 \mathrm{hPa}$.

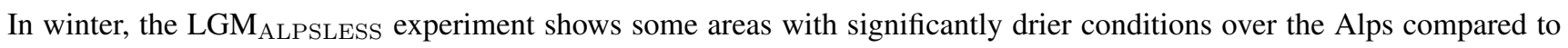
LGM $_{\text {LGM }}$ (Fig. 10a), especially in the western Alps with some significant precipitation reductions of up to $6 \mathrm{~mm} \mathrm{day}^{-1}$. This dryness generally coincides with the reduced Alpine ice-sheet thickness (Fig. 2c). Interestingly, the reduction in precipitation is higher in the western part than in the central to eastern part of the Alps, although the Alpine ice-sheet thickness is reduced more strongly in the east than in the west (Fig. 2c). In summer, changes of the Alpine ice sheet go along with a significant north-south precipitation pattern (Fig. 10b). Most of the significant precipitation changes are found in the central to eastern Alps, whereas only a small reduction in precipitation is evident in the western part. Thus, this modification in summer follows the west east gradient of the Alpine ice-sheet thickness reduction (Fig. 2c). Overall, both seasons demonstrate that locally heterogeneous changes in the topography significantly influence local precipitation patterns over the Alps. 
To further understand these precipitation changes, we investigate the vertical profiles at the two sites (Fig. 2) and the wind field at $700 \mathrm{hPa}$. The Skew-T diagrams of both sites and both seasons show no structural change in the temperature, moisture, and thus the stability of the atmosphere when comparing the LGM ALPSLESS $_{\text {with }}$ the GM $_{\mathrm{LGM}}$ simulation (therefore not shown). This is somehow expected, since the two sites are located in areas where the Alpine ice sheet is not present. Nevertheless, we interpret this result that precipitation changes are restricted to the area where the ice sheet is changed, i.e., no downstream effects are found in the temperature and moisture profiles and thus in the stability. This is in contrast to wind, where some changes are evident at both sites. These changes are better illustrated in the wind field at $700 \mathrm{hPa}$ (Fig. 11). In

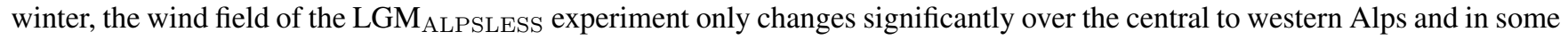

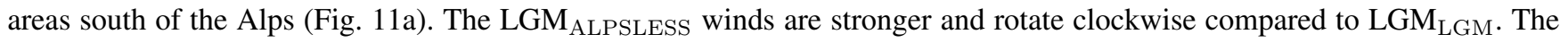
rotation is associated with significant changes in $\mathrm{V}$ at the northern face of the Alps, in both wind components over the Alpine axis and in $\mathrm{U}$ in the south of the Alps (Fig. 11a). During summer, we overall observe a similar behaviour as in winter but with an eastward extension of the changes.

In summary, precipitation changes in both seasons are associated with the fact that the wind field faces a lower orographic barrier due to a reduction of the Alpine ice sheet. This effect results in reduced (increased) precipitation at the northern face of the Alps in winter (summer). Additionally, this leads to drying the south-western Alps in winter and the southern face of the Alps in summer.

\section{Discussion and conclusions}

In this study, we investigate the sensitivity of the glacial Alpine hydro-climate to northern hemispheric and local ice-sheet changes. To that end, we employ a GCM-RCM model chain to perform sensitivity simulations for two glacial periods, the LGM and MIS4. The LGM is compared to the PD and MIS4 climate simulation in order to characterise these glacial states. Then, we assess the impact of northern hemispheric ice-sheet thickness on the Alpine hydro-climate under MIS4 and LGM conditions. The second sensitivity test uses LGM conditions as base line and assesses the hydro-climatic response to changes in the Alpine ice sheet.

The LGM is known to be a period of generally drier and colder conditions than today (Otto-Bliesner et al., 2006). Earlier studies using the same LGM WRF simulation (e.g. Velasquez et al., 2020b, a) showed that an application of the GCM-RCM model chain is beneficial with respect to temperature and precipitation over Europe compared to the driving GCM (Hofer et al., 2012a, b; Merz et al., 2013, 2014a, b, 2015, 2016) and other global model simulations (e.g. Kageyama et al., 2017, 2021), since the last ones underestimate the temperature amplitude between PD and LGM.

Here, we focus the analysis on the hydro-climate over the Alps. In winter, we find wetter conditions in the southern part of the Alps during LGM compared to PD (Frei and Schär, 1998; Schwarb et al., 2001). The northern part, however, is dryer under LGM conditions, which is expected due to the general colder conditions of the LGM (as the Clausius-Clapeyron equation suggests). This enhanced north-south precipitation gradient resembles finding of Becker et al. (2016) showing that such a gradient is a prerequisite to explain the extent of the Alpine glacier during the LGM. Even though LGM climate was colder 
https://doi.org/10.5194/cp-2021-67

Preprint. Discussion started: 21 June 2021

(c) Author(s) 2021. CC BY 4.0 License.

(c) (i)

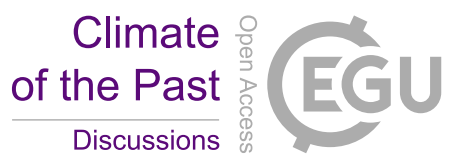

with lower mixing ratios, our analysis shows that changes in the wind speed and direction substantially contribute to the north-south precipitation pattern. Winds are significantly stronger and anticlockwise rotated over the Alpine region during LGM suggesting an increase of intensity or frequency of the moisture advection from the south to the Alps. This is in line with proxy evidence (Florineth and Schlüchter, 2000; Luetscher et al., 2015). These authors similarly found a circulation change from dominant westerlies during PD to a more southern atmospheric circulation during the LGM. To explain these changes, global modelling studies suggested a southward shift of the North Atlantic storm track during the LGM compared to PD (e.g. Hofer et al., 2012a; Luetscher et al., 2015; Merz et al., 2015; Raible et al., 2020) and a change in the weather patterns (e.g. Hofer et al., 2012b; Ludwig et al., 2016; Wang et al., 2018). Thus, our analysis shows that changes in the atmospheric dynamics on the regional to local scale are also relevant to explain precipitation changes, in particular the moistening of the southern face of the Alps. During summer, we find drier conditions in most of the Alpine domain. This is expected, as the LGM is generally colder than PD (Clausius-Clapeyron equation). Additionally, we find a strong reduction in convective activity, which can be traced back to a colder atmospheric state and an increase in stability during the LGM compared to PD.

The MIS4 climate shows enhanced winter precipitation compared to the LGM. The reason is that the MIS4 climate state is warmer (Hofer et al., 2012a, b; Merz et al., 2013, 2014a, b, 2015, 2016) and thus more moisture is available. Wind changes do not contribute to these wetter conditions as they become weaker and therefore reduce the moisture transport and orographically forced uplifts. Thus, we interpret the winter changes between MIS4 and LGM to be purely thermodynamically driven (Clausius-Clapeyron equation). In summer, MIS4 $_{\text {LGM }}$ shows slightly wetter conditions at the northern face and drier conditions at the southern side of the Alps during MIS4 $_{\text {LGM }}$. The wetter conditions are induced by an increase in the tropospheric vertical wind shear enhancing convection processes. The drier conditions at the southern face of the Alps are explained by slightly clockwise rotated winds, which enhance the Foehn effect. Thus, for summer also dynamical processes are relevant to explain the precipitation changes between MIS4 and LGM.

The northern hemispheric ice-sheet topography strongly influences the precipitation over the Alpine region. In both seasons, the precipitation patterns and the related thermodynamic and dynamic processes are similar to the ones found in the comparison between the LGM and PD. Namely, an increase of the northern hemispheric ice sheet leads to an intensification of glacial conditions over the Alps. Changes in the FIS do only weakly alter the precipitation patterns over the Alpine region. One potential reason of this weak precipitation response may also be the design of the Fennoscandian sensitivity experiment as the driving GCM has not experienced the changes of the FIS. However, we introduced rather strong changes in the RCM; thus, we expect only a minor impact of the experimental design on the conclusion that the FIS is less influential on the Alpine precipitation. We further conclude that changes in the Laurentide ice sheet needs to be considered in the estimation of Alpine precipitation. Moreover, the analysis shows that the northern hemispheric ice-sheet thickness is mainly responsible for the dynamical processes explaining the precipitation changes. This is suggested by the similarity of the processes found in the sensitivity experiments of northern hemispheric ice-sheet thickness and in the comparison between the LGM and PD.

In the assessment of the role of the Alpine ice-sheet topography, we found significant changes mainly over the area where the ice sheet was altered and south to this area, e.g. south to the Alps during summer. These changes are not as strong as the ones identified for changes in the northern hemispheric ice sheet or between LGM and PD. Nevertheless, they are responsible 
https://doi.org/10.5194/cp-2021-67

Preprint. Discussion started: 21 June 2021

(c) Author(s) 2021. CC BY 4.0 License.

(c) (i)

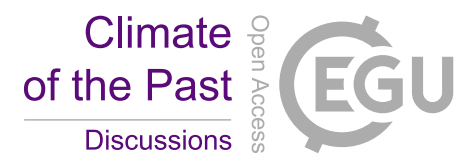

430 for a redistribution of precipitation over the Alps, e.g. a stronger reduction in the western part than in the central and eastern part during winter. These changes are relevant for glacier modelling (e.g. Jouvet et al., 2017; Seguinot et al., 2018). Thus, the analysis presented here suggests that future modelling efforts should ideally involve coupled glacier regional climate models. At the moment, this is not possible due to the long calculation time needed for glacier models and the high computational cost of RCMs. An intermediate step is to use the output of different sensitivity simulations, as presented here, in ice-sheet modelling studies (e.g. Jouvet et al., 2017; Seguinot et al., 2018).

Moreover, future studies will benefit from even more detailed climate simulations over the Alpine region, particularly to better understand precipitation patterns in complex terrain. Both, the climate variables but also a better understanding of the ice-sheet dynamics would be beneficial for studies on the local and regional paleobotany (Kaplan et al., 2016), archaeology (Burke et al., 2017; Wren and Burke, 2019) and anthropology (e.g. Finlayson, 2004; Finlayson et al., 2006; Finlayson, 2008;

440 Burke et al., 2014; Maier et al., 2016; Baena Preysler et al., 2019).

Author contributions. PV and CCR contributed to the design of the experiments. PV carried out the climate simulations and wrote the first draft. M.M. provided support in the initialisation of WRF and in the performance of the base-line simulations (PD and LGM). All authors contributed to the interpretation of the results, the writing, and scientific discussion.

Competing interests. The authors declare no competing interests.

445 Acknowledgements. This work was supported by the Swiss National Science Foundation (SNF) within the project 'Modelling the ice flow in the western Alps during the last glacial cycle'. MM is supported by the SNF Early Postdoc Mobility programme. The simulations are performed on the super computing architecture of the Swiss National Supercomputing Centre (CSCS). Data is locally stored on the oschgerstore provided by the Oeschger Center for Climate Change Research (OCCR). 
https://doi.org/10.5194/cp-2021-67

Preprint. Discussion started: 21 June 2021

(c) Author(s) 2021. CC BY 4.0 License.

(c) (i)

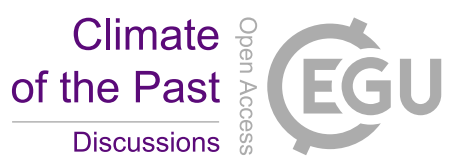

\section{References}

Abe-Ouchi, A., Saito, F., Kageyama, M., Braconnot, P., Harrison, S. P., Lambeck, K., Otto-Bliesner, B. L., Peltier, W. R., Tarasov, L., Peterschmitt, J.-Y., and Takahashi, K.: Ice-sheet configuration in the CMIP5/PMIP3 Last Glacial Maximum experiments, Geoscientific Model Development, 8, 3621-3637, https://doi.org/10.5194/gmd-8-3621-2015, 2015.

Angelis, H. D. and Kleman, J.: Palaeo-ice streams in the northern Keewatin sector of the Laurentide ice sheet, Annals of Glaciology, 42, 135-144, https://doi.org/10.3189/172756405781812925, 2005.

Annan, J. D. and Hargreaves, J. C.: A new global reconstruction of temperature changes at the Last Glacial Maximum, Climate of the Past, 9, 367-376, https://doi.org/10.5194/cp-9-367-2013, publisher: Copernicus GmbH, 2013.

AWC: The use of the Skew T, Log P diagram in analysis and forecasting. Manual 105-124, Tech. rep., Air Weather Service, Department of the Air Force, Illinois, USA, 1969.

AWC: The use of the Skew T, Log P diagram in analysis and forecasting. Technical report TR-79/006 (1979), revised, Tech. rep., Air Weather Service, Department of the Air Force, Illinois, USA, 1990.

Baena Preysler, J., Carrión Santafé, E., Torres Navas, C., and Vaquero Rodríguez, M.: Mousterian inside the upper Paleolithic? The last interval of El Esquilleu (Cantabria, Spain) sequence, Quaternary International, 508, 153-163, https://doi.org/10.1016/j.quaint.2018.11.015, 2019.

Ban, N., Schmidli, J., and Schär, C.: Evaluation of the convection-resolving regional climate modeling approach in decade-long simulations, Journal of Geophysical Research: Atmospheres, 119, 7889-7907, https://doi.org/10.1002/2014JD021478, 2014.

Bartlein, P. J., Harrison, S. P., Brewer, S., Connor, S., Davis, B. A. S., Gajewski, K., Guiot, J., Harrison-Prentice, T. I., Henderson, A., Peyron, O., Prentice, I. C., Scholze, M., Seppä, H., Shuman, B., Sugita, S., Thompson, R. S., Viau, A. E., Williams, J., and Wu, H.: Pollen-based continental climate reconstructions at 6 and $21 \mathrm{ka}$ a global synthesis, Climate Dynamics, 37, 775-802, https://doi.org/10.1007/s00382010-0904-1, 2011.

Batchelor, C. L., Margold, M., Krapp, M., Murton, D. K., Dalton, A. S., Gibbard, P. L., Stokes, C. R., Murton, J. B., and Manica, A.: The configuration of Northern Hemisphere ice sheets through the Quaternary, Nature Communications, 10, 3713, https://doi.org/10.1038/s41467019-11601-2, 2019.

Becker, P., Seguinot, J., Jouvet, G., and Funk, M.: Last Glacial Maximum precipitation pattern in the Alps inferred from glacier modelling, Geographica Helvetica, 71, 173-187, https://doi.org/10.5194/gh-71-173-2016, 2016.

Beghin, P., Charbit, S., Kageyama, M., Combourieu-Nebout, N., Hatté, C., Dumas, C., and Peterschmitt, J.-Y.: What drives LGM precipitation over the western Mediterranean? A study focused on the Iberian Peninsula and northern Morocco, Climate Dynamics, 46, 2611-2631, https://doi.org/10.1007/s00382-015-2720-0, 2016.

Braconnot, P., Harrison, S. P., Kageyama, M., Bartlein, P. J., Masson-Delmotte, V., Abe-Ouchi, A., Otto-Bliesner, B., and Zhao, Y.: Evaluation of climate models using palaeoclimatic data, Nature Climate Change, 2, 417-424, https://doi.org/10.1038/nclimate1456, 2012.

Burke, A., Levavasseur, G., James, P. M. A., Guiducci, D., Izquierdo, M. A., Bourgeon, L., Kageyama, M., Ramstein, G., and Vrac, M.: Exploring the impact of climate variability during the Last Glacial Maximum on the pattern of human occupation of Iberia, Journal of Human Evolution, 73, 35-46, https://doi.org/10.1016/j.jhevol.2014.06.003, 2014.

Burke, A., Kageyama, M., Latombe, G., Fasel, M., Vrac, M., Ramstein, G., and James, P. M. A.: Risky business: The impact of climate and climate variability on human population dynamics in Western Europe during the Last Glacial Maximum, Quaternary Science Reviews, 164, 217-229, https://doi.org/10.1016/j.quascirev.2017.04.001, 2017. 
https://doi.org/10.5194/cp-2021-67

Preprint. Discussion started: 21 June 2021

(c) Author(s) 2021. CC BY 4.0 License.

Chen, J., Dai, A., Zhang, Y., and Rasmussen, K. L.: Changes in Convective Available Potential Energy and Convective Inhibition under Global Warming, Journal of Climate, 33, 2025-2050, https://doi.org/10.1175/JCLI-D-19-0461.1, publisher: American Meteorological Society Section: Journal of Climate, 2020.

Clark, P. U., Dyke, A. S., Shakun, J. D., Carlson, A. E., Clark, J., Wohlfarth, B., Mitrovica, J. X., Hostetler, S. W., and McCabe, A. M.: The Last Glacial Maximum, Science, 325, 710-714, https://doi.org/10.1126/science.1172873, 2009.

Cleator, S. F., Harrison, S. P., Nichols, N. K., Prentice, I. C., and Roulstone, I.: A new multivariable benchmark for Last Glacial Maximum climate simulations, Climate of the Past, 16, 699-712, https://doi.org/10.5194/cp-16-699-2020, 2020.

Cutler, K. B., Edwards, R. L., Taylor, F. W., Cheng, H., Adkins, J., Gallup, C. D., Cutler, P. M., Burr, G. S., and Bloom, A. L.: Rapid sea-level fall and deep-ocean temperature change since the last interglacial period, Earth and Planetary Science Letters, 206, 253-271, https://doi.org/10.1016/S0012-821X(02)01107-X, 2003.

da Silva, F. P., Rotunno Filho, O. C., Sampaio, R. J., Dragaud, I. C. D. V., de Araújo, A. A. M., Justi da Silva, M. G. A., and Pires, G. D.: Evaluation of atmospheric thermodynamics and dynamics during heavy-rainfall and no-rainfall events in the metropolitan area of Rio de Janeiro, Brazil, Meteorology and Atmospheric Physics, 131, 299-311, https://doi.org/10.1007/s00703-017-0570-5, 2019.

De Deckker, P., Arnold, L. J., van der Kaars, S., Bayon, G., Stuut, J.-B. W., Perner, K., Lopes dos Santos, R., Uemura, R., and Demuro, M.: Marine Isotope Stage 4 in Australasia: A full glacial culminating 65,000 years ago - Global connections and implications for human dispersal, Quaternary Science Reviews, 204, 187-207, https://doi.org/10.1016/j.quascirev.2018.11.017, 2019.

de Vernal, A., Rosell-Melé, A., Kucera, M., Hillaire-Marcel, C., Eynaud, F., Weinelt, M., Dokken, T., and Kageyama, M.: Comparing proxies for the reconstruction of LGM sea-surface conditions in the northern North Atlantic, Quaternary Science Reviews, 25, 28202834, https://doi.org/10.1016/j.quascirev.2006.06.006, 2006.

Duarte, R. P. and Gomes, A. J.: Real-time simulation of cumulus clouds through SkewT/LogP diagrams, Computers and Graphics, 67, 103-114, https://doi.org/10.1016/j.cag.2017.06.005, 2017.

Eggleston, S., Schmitt, J., Bereiter, B., Schneider, R., and Fischer, H.: Evolution of the stable carbon isotope composition of atmospheric CO2 over the last glacial cycle, Paleoceanography, 31, 434-452, https://doi.org/10.1002/2015PA002874, 2016.

Ehlers, J., Gibbard, P., and Hughes, P.: Quaternary glaciations-extent and chronology: a closer look, vol. 15, Elsevier, Amsterdam, Netherlands, 2011.

Finlayson, C.: Neanderthals and modern humans: an ecological and evolutionary perspective, vol. 38, Cambridge University Press, 2004.

Finlayson, C.: On the importance of coastal areas in the survival of Neanderthal populations during the Late Pleistocene, Quaternary Science Reviews, 27, 2246-2252, https://doi.org/10.1016/j.quascirev.2008.08.033, 2008.

Finlayson, C., Giles Pacheco, F., Rodríguez-Vidal, J., Fa, D. A., María Gutierrez López, J., Santiago Pérez, A., Finlayson, G., Allue, E., 515 Baena Preysler, J., Cáceres, I., Carrión, J. S., Fernández Jalvo, Y., Gleed-Owen, C. P., Jimenez Espejo, F. J., López, P., Antonio López Sáez, J., Antonio Riquelme Cantal, J., Sánchez Marco, A., Giles Guzman, F., Brown, K., Fuentes, N., Valarino, C. A., Villalpando, A., Stringer, C. B., Martinez Ruiz, F., and Sakamoto, T.: Late survival of Neanderthals at the southernmost extreme of Europe, Nature, 443, 850-853, https://doi.org/10.1038/nature05195, 2006.

Florineth, D. and Schlüchter, C.: Alpine Evidence for Atmospheric Circulation Patterns in Europe during the Last Glacial Maximum, Quaternary Research, 54, 295-308, https://doi.org/10.1006/qres.2000.2169, 2000.

Frei, C. and Schär, C.: A precipitation climatology of the Alps from high-resolution rain-gauge observations, International Journal of Climatology, 18, 873-900, https://doi.org/10.1002/(SICI)1097-0088(19980630)18:8<873::AID-JOC255>3.0.CO;2-9, 1998. 
https://doi.org/10.5194/cp-2021-67

Preprint. Discussion started: 21 June 2021

(c) Author(s) 2021. CC BY 4.0 License.

(c) (i)

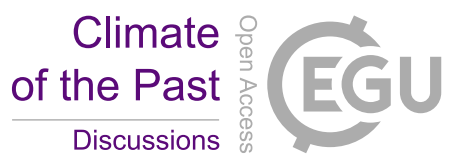

Ganopolski, A. and Brovkin, V.: Simulation of climate, ice sheets and $\mathrm{CO}_{2}$ evolution during the last four glacial cycles with an Earth system model of intermediate complexity, Climate of the Past, 13, 1695-1716, https://doi.org/10.5194/cp-13-1695-2017, 2017.

Ganopolski, A. and Calov, R.: The role of orbital forcing, carbon dioxide and regolith in 100 kyr glacial cycles, Climate of the Past, 7, 1415-1425, https://doi.org/10.5194/cp-7-1415-2011, 2011.

Gent, P. R., Danabasoglu, G., Donner, L. J., Holland, M. M., Hunke, E. C., Jayne, S. R., Lawrence, D. M., Neale, R. B., Rasch, P. J., Vertenstein, M., Worley, P. H., Yang, Z.-L., and Zhang, M.: The Community Climate System Model Version 4, Journal of Climate, 24 , 4973-4991, https://doi.org/10.1175/2011JCLI4083.1, 2011.

Gómez-Navarro, J. J., Raible, C. C., Bozhinova, D., Martius, O., García Valero, J. A., and Montávez, J. P.: A new region-aware biascorrection method for simulated precipitation in areas of complex orography, Geoscientific Model Development, 11, 2231-2247, https://doi.org/10.5194/gmd-11-2231-2018, 2018.

Gowan, E. J., Zhang, X., Khosravi, S., Rovere, A., Stocchi, P., Hughes, A. L. C., Gyllencreutz, R., Mangerud, J., Svendsen, J.I., and Lohmann, G.: A new global ice sheet reconstruction for the past 80000 years, Nature Communications, 12, 1199, https://doi.org/10.1038/s41467-021-21469-w, 2021.

Harrison, S. P., Bartlein, P. J., Izumi, K., Li, G., Annan, J., Hargreaves, J., Braconnot, P., and Kageyama, M.: Evaluation of CMIP5 palaeosimulations to improve climate projections, Nature Climate Change, 5, 735-743, https://doi.org/10.1038/nclimate2649, 2015.

Harrison, S. P., Bartlein, P. J., and Prentice, I. C.: What have we learnt from palaeoclimate simulations?, Journal of Quaternary Science, 31, 363-385, https://doi.org/10.1002/jqs.2842, 2016.

Hofer, D., Raible, C. C., Dehnert, A., and Kuhlemann, J.: The impact of different glacial boundary conditions on atmospheric dynamics and precipitation in the North Atlantic region, Climate of the Past, 8, 935-949, https://doi.org/10.5194/cp-8-935-2012, 2012a.

Hofer, D., Raible, C. C., Merz, N., Dehnert, A., and Kuhlemann, J.: Simulated winter circulation types in the North Atlantic and European region for preindustrial and glacial conditions: Glacial circulation types, Geophysical Research Letters, 39, https://doi.org/10.1029/2012GL052296, 2012 b.

Hughes, P. D., Gibbard, P. L., and Ehlers, J.: Timing of glaciation during the last glacial cycle: evaluating the concept of a global 'Last Glacial Maximum' (LGM), Earth-Science Reviews, 125, 171-198, https://doi.org/10.1016/j.earscirev.2013.07.003, 2013.

Jouvet, G., Seguinot, J., Ivy-Ochs, S., and Funk, M.: Modelling the diversion of erratic boulders by the Valais Glacier during the last glacial maximum, Journal of Glaciology, 63, 487-498, https://doi.org/10.1017/jog.2017.7, 2017.

Kageyama, M. and Valdes, P. J.: Impact of the North American ice-sheet orography on the Last Glacial Maximum eddies and snowfall, Geophysical Research Letters, 27, 1515-1518, https://doi.org/10.1029/1999GL011274, 2000.

Kageyama, M., Albani, S., Braconnot, P., Harrison, S. P., Hopcroft, P. O., Ivanovic, R. F., Lambert, F., Marti, O., Peltier, W. R., Peterschmitt, J.-Y., Roche, D. M., Tarasov, L., Zhang, X., Brady, E. C., Haywood, A. M., LeGrande, A. N., Lunt, D. J., Mahowald, N. M., Mikolajewicz, U., Nisancioglu, K. H., Otto-Bliesner, B. L., Renssen, H., Tomas, R. A., Zhang, Q., Abe-Ouchi, A., Bartlein, P. J., Cao, J., Li, Q., Lohmann, G., Ohgaito, R., Shi, X., Volodin, E., Yoshida, K., Zhang, X., and Zheng, W.: The PMIP4 contribution to CMIP6 - Part 4: Scientific objectives and experimental design of the PMIP4-CMIP6 Last Glacial Maximum experiments and PMIP4 sensitivity experiments, Geoscientific Model Development, 10, 4035-4055, https://doi.org/10.5194/gmd-10-4035-2017, 2017.

Kageyama, M., Harrison, S. P., Kapsch, M.-L., Lofverstrom, M., Lora, J. M., Mikolajewicz, U., Sherriff-Tadano, S., Vadsaria, T., Abe-Ouchi, A., Bouttes, N., Chandan, D., Gregoire, L. J., Ivanovic, R. F., Izumi, K., LeGrande, A. N., Lhardy, F., Lohmann, G., Morozova, P. A., Ohgaito, R., Paul, A., Peltier, W. R., Poulsen, C. J., Quiquet, A., Roche, D. M., Shi, X., Tierney, J. E., Valdes, P. J., Volodin, E., and Zhu, 
https://doi.org/10.5194/cp-2021-67

Preprint. Discussion started: 21 June 2021

(c) Author(s) 2021. CC BY 4.0 License.

(c) (i)

J.: The PMIP4 Last Glacial Maximum experiments: preliminary results and comparison with the PMIP3 simulations, Climate of the Past, 17, 1065-1089, https://doi.org/10.5194/cp-17-1065-2021, publisher: Copernicus GmbH, 2021.

Kaplan, J. O., Pfeiffer, M., Kolen, J. C. A., and Davis, B. A. S.: Large scale anthropogenic reduction of forest cover in Last Glacial Maximum Europe, PLOS ONE, 11, e0166 726, https://doi.org/10.1371/journal.pone.0166726, 2016.

Kjellström, E., Brandefelt, J., Näslund, J.-O., Smith, B., Strandberg, G., Voelker, A. H. L., and Wohlfarth, B.: Simulated climate conditions

in Europe during the Marine Isotope Stage 3 stadial, Boreas, 39, 436-456, https://doi.org/10.1111/j.1502-3885.2010.00143.x, 2010.

Krauß, L., Zens, J., Zeeden, C., Schulte, P., Eckmeier, E., and Lehmkuhl, F.: A Multi-Proxy Analysis of two LoessPaleosol Sequences in the Northern Harz Foreland, Germany, Palaeogeography, Palaeoclimatology, Palaeoecology, 461, 401-417, https://doi.org/10.1016/j.palaeo.2016.09.001, 2016.

Lambeck, K., Rouby, H., Purcell, A., Sun, Y., and Sambridge, M.: Sea level and global ice volumes from the Last Glacial Maximum to the Holocene, Proceedings of the National Academy of Sciences, 111, 15 296-15 303, https://doi.org/10.1073/pnas.1411762111, 2014.

Lambert, F., Delmonte, B., Petit, J. R., Bigler, M., Kaufmann, P. R., Hutterli, M. A., Stocker, T. F., Ruth, U., Steffensen, J. P., and Maggi, V.: Dust-climate couplings over the past 800,000 years from the EPICA Dome C ice core, Nature, 452, 616-619, https://doi.org/10.1038/nature06763, 2008.

Latombe, G., Burke, A., Vrac, M., Levavasseur, G., Dumas, C., Kageyama, M., and Ramstein, G.: Comparison of spatial downscaling methods of general circulation model results to study climate variability during the Last Glacial Maximum, Geoscientific Model Development, 11, 2563-2579, https://doi.org/10.5194/gmd-11-2563-2018, 2018.

Leung, L. R., Mearns, L. O., Giorgi, F., and Wilby, R. L.: Regional climate research, Bulletin of the American Meteorological Society, 84, 89-95, https://doi.org/10.1175/BAMS-84-1-89, 2003.

Ludwig, P., Schaffernicht, E. J., Shao, Y., and Pinto, J. G.: Regional atmospheric circulation over Europe during the Last Glacial Maximum and its links to precipitation, Journal of Geophysical Research: Atmospheres, 121, 2130-2145, https://doi.org/10.1002/2015JD024444, 2016.

Ludwig, P., Pinto, J. G., Raible, C. C., and Shao, Y.: Impacts of surface boundary conditions on regional climate model simulations of European climate during the Last Glacial Maximum, Geophysical Research Letters, 44, 5086-5095, https://doi.org/10.1002/2017GL073622, 2017.

Ludwig, P., Gómez-Navarro, J. J., Pinto, J. G., Raible, C. C., Wagner, S., and Zorita, E.: Perspectives of regional paleoclimate modeling, Annals of the New York Academy of Sciences, 1436, 54-69, https://doi.org/10.1111/nyas.13865, 2019.

Luetscher, M., Boch, R., Sodemann, H., Spötl, C., Cheng, H., Edwards, R. L., Frisia, S., Hof, F., and Müller, W.: North Atlantic storm track changes during the Last Glacial Maximum recorded by Alpine speleothems, Nature Communications, 6, 6344, https://doi.org/10.1038/ncomms7344, number: 1 Publisher: Nature Publishing Group, 2015.

Maier, A., Lehmkuhl, F., Ludwig, P., Melles, M., Schmidt, I., Shao, Y., Zeeden, C., and Zimmermann, A.: Demographic estimates of hunter-gatherers during the Last Glacial Maximum in Europe against the background of palaeoenvironmental data, Quaternary International, 425, 49-61, https://doi.org/10.1016/j.quaint.2016.04.009, 2016.

Mayewski, P. A., Rohling, E. E., Stager, J. C., Karlén, W., Maasch, K. A., Meeker, L. D., Meyerson, E. A., Gasse, F., Kreveld, S. v., Holmgren, K., Lee-Thorp, J., Rosqvist, G., Rack, F., Staubwasser, M., Schneider, R. R., and Steig, E. J.: Holocene climate variability, Quaternary Research, 62, 243-255, https://doi.org/10.1016/j.yqres.2004.07.001, 2004. 
https://doi.org/10.5194/cp-2021-67

Preprint. Discussion started: 21 June 2021

(c) Author(s) 2021. CC BY 4.0 License.

(c) (i)

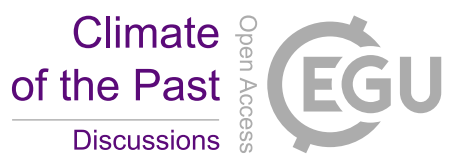

Merz, N., Raible, C. C., Fischer, H., Varma, V., Prange, M., and Stocker, T. F.: Greenland accumulation and its connection to the large-scale atmospheric circulation in ERA-Interim and paleoclimate simulations, Climate of the Past, 9, 2433-2450, https://doi.org/10.5194/cp-92433-2013, 2013.

Merz, N., Born, A., Raible, C. C., Fischer, H., and Stocker, T. F.: Dependence of Eemian Greenland temperature reconstructions on the ice sheet topography, Climate of the Past, 10, 1221-1238, https://doi.org/10.5194/cp-10-1221-2014, 2014a.

Merz, N., Gfeller, G., Born, A., Raible, C. C., Stocker, T. F., and Fischer, H.: Influence of ice sheet topography on Greenland precipitation during the Eemian interglacial, Journal of Geophysical Research: Atmospheres, 119, 10,749-10,768, https://doi.org/10.1002/2014JD021940, 2014 b.

Merz, N., Raible, C. C., and Woollings, T.: North Atlantic Eddy-Driven jet in interglacial and glacial winter climates, Journal of Climate, 28, 3977-3997, https://doi.org/10.1175/JCLI-D-14-00525.1, 2015.

Merz, N., Born, A., Raible, C. C., and Stocker, T. F.: Warm Greenland during the last interglacial: the role of regional changes in sea ice cover, Climate of the Past, 12, 2011-2031, https://doi.org/10.5194/cp-12-2011-2016, 2016.

Messmer, M., Gómez-Navarro, J. J., and Raible, C. C.: Climatology of Vb cyclones, physical mechanisms and their impact on extreme precipitation over Central Europe, Earth System Dynamics, 6, 541-553, https://doi.org/10.5194/esd-6-541-2015, 2015.

610 Messmer, M., Gómez-Navarro, J. J., and Raible, C. C.: Sensitivity experiments on the response of Vb cyclones to sea surface temperature and soil moisture changes, Earth System Dynamics, 8, 477-493, https://doi.org/10.5194/esd-8-477-2017, 2017.

Messmer, M., Raible, C. C., and Gómez-Navarro, J. J.: Impact of climate change on the climatology of Vb cyclones, Tellus A: Dynamic Meteorology and Oceanography, 72, 1-18, https://doi.org/10.1080/16000870.2020.1724021, 2020.

Mix, A. C., Bard, E., and Schneider, R.: Environmental processes of the ice age: land, oceans, glaciers (EPILOG), Quaternary Science Reviews, 20, 627-657, https://doi.org/10.1016/S0277-3791(00)00145-1, 2001.

Monegato, G., Scardia, G., Hajdas, I., Rizzini, F., and Piccin, A.: The Alpine LGM in the boreal ice-sheets game, Scientific Reports, 7, 2078, https://doi.org/10.1038/s41598-017-02148-7, 2017.

Morsy, M., Sayad, T., Khamees, A., and Ibrahim, M. M.: Stability Study of Severe Weather Event over Eastern Mediterranean, Al Azhar Bulletin of Science Vol. 9th, Conference, Tech. rep., Egypt, 2017.

Neale, R. B., Richter, J. H., Conley, A. J., Park, S., Lauritzen, P. H., Gettelman, A., Rasch, P. J., and Vavrus, J.: Description of the NCAR community atmosphere model (CAM4), National Center for Atmospheric Research Tech. Rep. NCAR/TN+ STR, http://www.cesm.ucar. edu/models/ccsm4.0/cam/docs/description/cam4_desc.pdf, 2010.

Newnham, R. M., Alloway, B. V., Holt, K. A., Butler, K., Rees, A. B. H., Wilmshurst, J. M., Dunbar, G., and Hajdas, I.: Last Glacial pollen-climate reconstructions from Northland, New Zealand, Journal of Quaternary Science, 32, 685-703, https://doi.org/10.1002/jqs.2955, 2017.

NOAA: Skew-T Parameters and Indices, National Weather Service, National Oceanic and Atmospheric Administration (NOAA), US Department of Commerce, https://www.weather.gov/source/zhu/ZHU_Training_Page/convective_parameters/skewt/skewtinfo.html, 2021.

Oleson, W., Lawrence, M., Bonan, B., Flanner, G., Kluzek, E., Lawrence, J., Levis, S., Swenson, C., Thornton, E., Dai, A., Decker, M., Dickinson, R., Feddema, J., Heald, L., Hoffman, F., Lamarque, J.-F., Mahowald, N., Niu, G.-Y., Qian, T., Randerson, J., Running, S., 630 Sakaguchi, K., Slater, A., Stockli, R., Wang, A., Yang, Z.-L., Zeng, X., and Zeng, X.: Technical description of version 4.0 of the community land model (CLM), NCAR Technical Note NCAR/TN-478+STR, National Center for Atmospheric Research, Boulder, CO, Boulder, CO, http://www.cesm.ucar.edu/models/cesm1.0/clm/CLM4_Tech_Note.pdf, national Center for Atmospheric Research, Boulder, CO, 2010. 
https://doi.org/10.5194/cp-2021-67

Preprint. Discussion started: 21 June 2021

(c) Author(s) 2021. CC BY 4.0 License.

(c) (i)

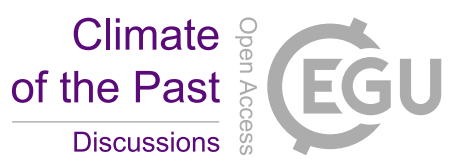

Otto-Bliesner, B. L., Brady, E. C., Clauzet, G., Tomas, R., Levis, S., and Kothavala, Z.: Last Glacial Maximum and Holocene Climate in CCSM3, Journal of Climate, 19, 2526-2544, https://doi.org/10.1175/JCLI3748.1, publisher: American Meteorological Society, 2006.

Pausata, F. S. R., Li, C., Wettstein, J., Kageyama, M., and Nisancioglu, K. H.: The key role of topography in altering North Atlantic atmospheric circulation during the last glacial period, Climate of the Past, https://doi.org/10.5194/cp-7-1089-2011, 2011.

Peltier, W.: Global glacial isostasy and the surface of the ice-age Earth: The ICE-5G (VM2) model and grace, Annual Review of Earth and Planetary Sciences, 32, 111-149, https://doi.org/10.1146/annurev.earth.32.082503.144359, 2004.

Peltier, W. R.: Ice Age Paleotopography, Science, 265, 195-201, https://doi.org/10.1126/science.265.5169.195, 1994.

Peltier, W. R.: Postglacial variations in the level of the sea: Implications for climate dynamics and solid-Earth geophysics, Reviews of Geophysics, 36, 603-689, https://doi.org/10.1029/98RG02638, 1998.

Peltier, W. R., Argus, D. F., and Drummond, R.: Space geodesy constrains ice age terminal deglaciation: The global ICE-6G_C (VM5a) model, Journal of Geophysical Research: Solid Earth, 120, 450-487, https://doi.org/10.1002/2014JB011176, 2015.

Pinto, J. G. and Ludwig, P.: Extratropical cyclones over the North Atlantic and western Europe during the Last Glacial Maximum and implications for proxy interpretation, Climate of the Past, 16, 611-626, https://doi.org/10.5194/cp-16-611-2020, 2020.

Prentice, I. C. and Jolly, D.: Mid-Holocene and glacial-maximum vegetation geography of the northern continents and Africa, Journal of Biogeography, 27, 507-519, https://doi.org/10.1046/j.1365-2699.2000.00425.x, 2000.

Raible, C. C., Pinto, J. G., Ludwig, P., and Messmer, M.: A review of past changes in extratropical cyclones in the northern hemisphere and what can be learned for the future, Wiley Interdisciplinary Reviews: Climate Change, p. e680, https://doi.org/10.1002/wcc.680, 2020.

Rivière, G., Laîné, A., Lapeyre, G., Salas-Mélia, D., and Kageyama, M.: Links between Rossby Wave Breaking and the North Atlantic Oscillation-Arctic Oscillation in Present-Day and Last Glacial Maximum Climate Simulations, Journal of Climate, 23, 2987-3008, https://doi.org/10.1175/2010JCLI3372.1, 2010.

Römer, W., Lehmkuhl, F., and Sirocko, F.: Late Pleistocene aeolian dust provenances and wind direction changes reconstructed by heavy mineral analysis of the sediments of the Dehner dry maar (Eifel, Germany), Global and Planetary Change, 147, 25-39, https://doi.org/10.1016/j.gloplacha.2016.10.012, 2016.

Rummukainen, M.: Added value in regional climate modeling, WIREs Climate Change, 7, 145-159, https://doi.org/10.1002/wcc.378, 2016.

Schwarb, M., Daly, C., Frei, C., and Schär, C.: Mean annual and seasonal precipitation in the European Alps 1971-1990, Hydrological Atlas of Switzerland, Landeshydrologie und Geologie, Bern, Switzerland, 2001.

Seguinot, J., Ivy-Ochs, S., Jouvet, G., Huss, M., Funk, M., and Preusser, F.: Modelling last glacial cycle ice dynamics in the Alps, The Cryosphere, 12, 3265-3285, https://doi.org/10.5194/tc-12-3265-2018, 2018.

Siddall, M., Rohling, E. J., Thompson, W. G., and Waelbroeck, C.: Marine isotope stage 3 sea level fluctuations: Data synthesis and new outlook, Reviews of Geophysics, 46, https://doi.org/10.1029/2007RG000226, 2008.

Siddall, M., Kaplan, M. R., Schaefer, J. M., Putnam, A., Kelly, M. A., and Goehring, B.: Changing influence of Antarctic and Greenlandic temperature records on sea-level over the last glacial cycle, Quaternary Science Reviews, 29, 410-423, https://doi.org/10.1016/j.quascirev.2009.11.007, 2010.

Skamarock, W. C. and Klemp, J. B.: A time-split nonhydrostatic atmospheric model for weather research and forecasting applications, Journal of Computational Physics, 227, 3465-3485, https://doi.org/10.1016/j.jcp.2007.01.037, 2008.

Skamarock, W. C., Klemp, J. B., Dudhia, J., Gill, O., Barker, D., Duda, G., Huang, X.-y., Wang, W., and Powers, G.: A description of the advanced research WRF version 3, https://doi.org/10.5065/D68S4MVH, 2008. 
https://doi.org/10.5194/cp-2021-67

Preprint. Discussion started: 21 June 2021

(c) Author(s) 2021. CC BY 4.0 License.

(c) (i)

Stocker, T. F. and Johnsen, S. J.: A minimum thermodynamic model for the bipolar seesaw, Paleoceanography, 18, https://doi.org/10.1029/2003PA000920, 2003.

Strandberg, G., Brandefelt, J., Kjellstro M., E., and Smith, B.: High-resolution regional simulation of Last Glacial Maximum climate in Europe, Tellus A: Dynamic Meteorology and Oceanography, 63, 107-125, https://doi.org/10.1111/j.1600-0870.2010.00485.x, 2011.

Su, F., Duan, X., Chen, D., Hao, Z., and Cuo, L.: Evaluation of the global climate models in the CMIP5 over the Tibetan Plateau, Journal of Climate, 26, 3187-3208, https://doi.org/10.1175/JCLI-D-12-00321.1, 2012.

Tarasov, L., Dyke, A. S., Neal, R. M., and Peltier, W. R.: A data-calibrated distribution of deglacial chronologies for the North American ice complex from glaciological modeling, Earth and Planetary Science Letters, 315-316, 30-40, https://doi.org/10.1016/j.epsl.2011.09.010, 2012.

Ullman, D. J., LeGrande, A. N., Carlson, A. E., Anslow, F. S., and Licciardi, J. M.: Assessing the impact of Laurentide Ice Sheet topography on glacial climate, Climate of the Past, 10, 487-507, https://doi.org/10.5194/cp-10-487-2014, 2014.

Van Meerbeeck, C. J., Renssen, H., and Roche, D. M.: How did Marine Isotope Stage 3 and Last Glacial Maximum climates differ? Perspectives from equilibrium simulations, Climate of the Past, 5, 33-51, https://doi.org/https://doi.org/10.5194/cp-5-33-2009, 2009.

Velasquez, P., Kaplan, J. O., Messmer, M., Ludwig, P., and Raible, C. C.: The role of land cover on the climate of glacial Europe, Climate of the Past Discussions, pp. 1-26, https://doi.org/10.5194/cp-2020-147, 2020a.

Velasquez, P., Messmer, M., and Raible, C. C.: A new bias-correction method for precipitation over complex terrain suitable for different climate states: a case study using WRF (version 3.8.1), Geoscientific Model Development, 13, 5007-5027, https://doi.org/10.5194/gmd13-5007-2020, 2020b.

Wallace, J. M. and Hobbs, P. V.: Atmospheric science: an introductory survey, vol. 92, Elsevier, 2006.

Wang, N., Jiang, D., and Lang, X.: Northern Westerlies during the Last Glacial Maximum: Results from CMIP5 Simulations, Journal of Climate, 31, 1135-1153, https://doi.org/10.1175/JCLI-D-17-0314.1, 2018.

Wilks, D. S.: Statistical methods in the atmospheric sciences, Academic Press, google-Books-ID: IJuCVtQ0ySIC, 2011.

Wren, C. D. and Burke, A.: Habitat suitability and the genetic structure of human populations during the Last Glacial Maximum (LGM) in Western Europe, PLOS ONE, 14, e0217 996, https://doi.org/10.1371/journal.pone.0217996, publisher: Public Library of Science, 2019.

Wu, H., Guiot, J., Brewer, S., and Guo, Z.: Climatic changes in Eurasia and Africa at the last glacial maximum and mid-Holocene: reconstruction from pollen data using inverse vegetation modelling, Climate Dynamics, 29, 211-229, https://doi.org/10.1007/s00382-007-0231-3, 2007.

Yokoyama, Y., Lambeck, K., De Deckker, P., Johnston, P., and Fifield, L. K.: Timing of the Last Glacial Maximum from observed sea-level minima, Nature, 406, 713-716, https://doi.org/10.1038/35021035, 2000. 
https://doi.org/10.5194/cp-2021-67

Preprint. Discussion started: 21 June 2021

(C) Author(s) 2021. CC BY 4.0 License.

Table 1. External forcing used in Hofer et al. (2012a, b) for 1990 CE, LGM and MIS4 conditions.

\begin{tabular}{lrrr} 
Parameter name & 1990 CE & LGM & MIS4 \\
\hline TSI $\left(\mathrm{W} \mathrm{m}^{-2}\right)$ & 1361.77 & 1360.89 & 1360.89 \\
Eccentricity $\left(10^{-2}\right)$ & 1.6708 & 1.8994 & 2.0713 \\
Obliquity $\left(^{\circ}\right)$ & 23.441 & 22.949 & 22.564 \\
Angular precession $\left(^{\circ}\right)$ & 102.72 & 114.43 & 15.22 \\
$\mathrm{CO}_{2}(\mathrm{ppm})$ & 353.9 & 185 & 205 \\
$\mathrm{CH}_{4}(\mathrm{ppb})$ & 1693.6 & 350 & 460 \\
$\mathrm{~N}_{2} \mathrm{O}(\mathrm{ppb})$ & 310.1 & 200 & 210
\end{tabular}




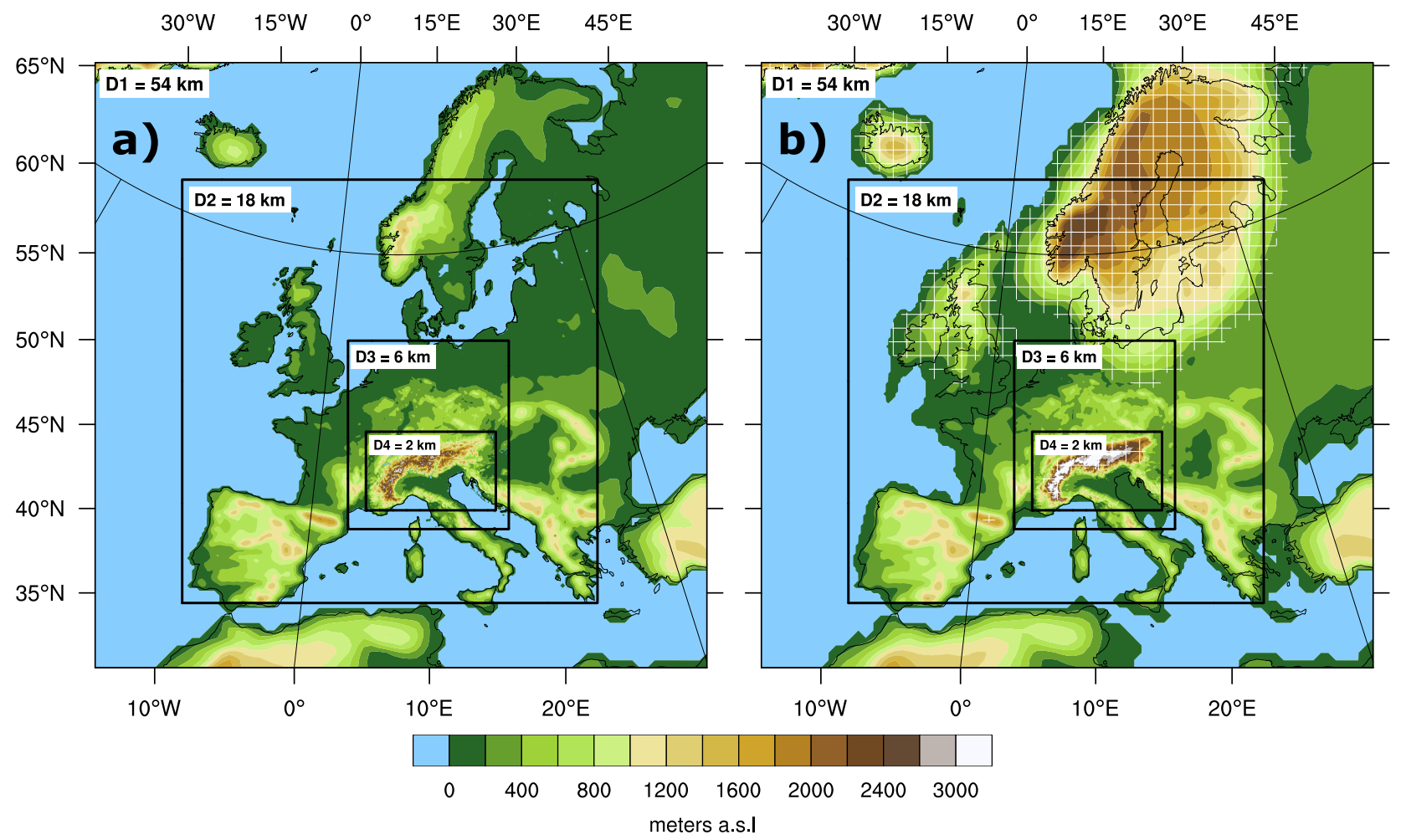

Figure 1. Domains and topography used by WRF. (a) represents the four domains at 54, 18, 6 and 2 km horizontal resolution and the shading indicates present-day topography, (b) as (a) but for the LGM topography, crosshatched areas are covered by glaciers. 
https://doi.org/10.5194/cp-2021-67

Preprint. Discussion started: 21 June 2021

(c) Author(s) 2021. CC BY 4.0 License.

(c) (i)

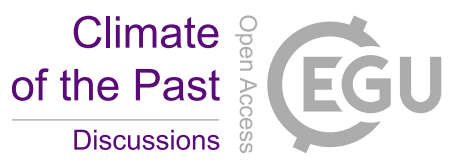

a) PD

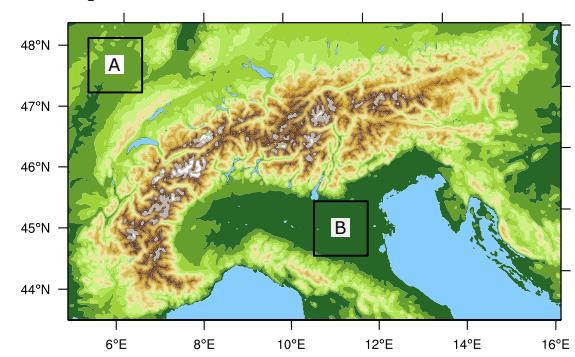

b) LGM

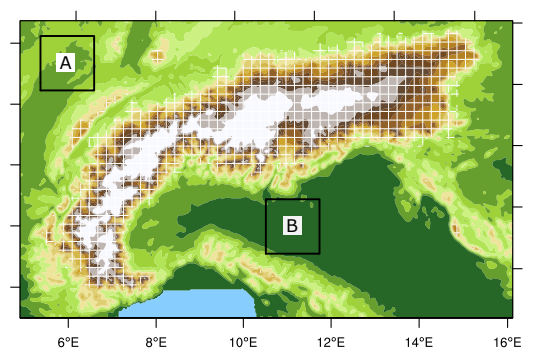

c) Diff. LGM ALPSLESS $_{\text {- LGM }}$

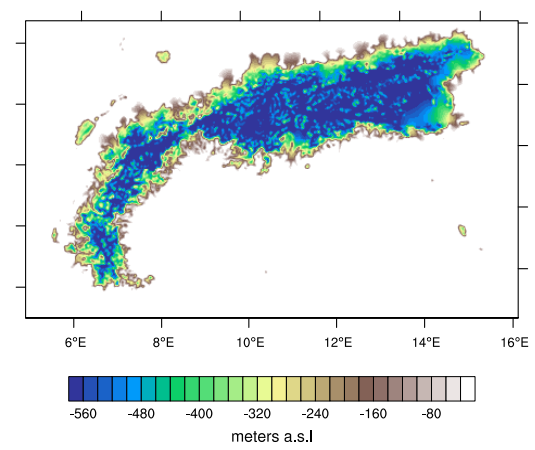

Figure 2. Innermost domain and topography used by WRF. (a) represents the domain at $2 \mathrm{~km}$ horizontal resolution and the shading indicates PD topography, (b) as (a) but for the LGM topography, crosshatched areas are covered by glaciers. (c) shows the difference between LGM $_{\text {ALPSLESS }}$ and LGM topography. The boxes in (a) and (b) are the two regions used for the Skew-T diagrams: Site A represents the north-western and site $\mathrm{B}$ the central-southern region. 
https://doi.org/10.5194/cp-2021-67

Preprint. Discussion started: 21 June 2021

(c) Author(s) 2021. CC BY 4.0 License.

(c) (i)

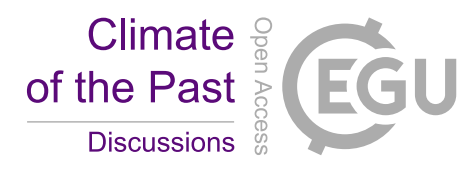

Table 2. Set of experiments carried out in this study. The first column indicates the name of the WRF simulation, the second column the perpetual conditions, the third column the northern hemispheric ice sheets (this includes the modifications in the driving global model), the fourth column the FIS, the fifth column the Alpine glaciers, the sixth column the land cover, and the seventh column the length of the simulation.

\begin{tabular}{|c|c|c|c|c|c|c|}
\hline Name & $\begin{array}{l}\text { Perpetual } \\
\text { conditions }\end{array}$ & $\begin{array}{l}\text { North Hemis. } \\
\text { ice sheets }\end{array}$ & $\begin{array}{c}\text { Fennoscandian } \\
\text { ice sheet }\end{array}$ & $\begin{array}{l}\text { Alpine } \\
\text { glaciers }\end{array}$ & $\begin{array}{l}\text { Land } \\
\text { cover }\end{array}$ & $\begin{array}{c}\text { Simulation } \\
\text { length }\end{array}$ \\
\hline $\mathrm{PD}_{\mathrm{PD}}$ & 1990 & 1990 & 1990 & 1990 & 1990 & 21 years \\
\hline $\mathrm{LGM}_{\mathrm{LGM}}$ & LGM & LGM & LGM & LGM & LGM & 21 years \\
\hline MIS4 $_{\text {LGM66 }}$ & MIS4 & $66 \%$ LGM & $66 \%$ LGM & LGM & LGM & 21 years \\
\hline MIS4 $_{\text {LGM }}$ & MIS4 & $100 \%$ LGM & $100 \%$ LGM & LGM & LGM & 21 years \\
\hline MIS4 $_{\text {LGM125 }}$ & MIS4 & $125 \%$ LGM & $125 \%$ LGM & LGM & LGM & 21 years \\
\hline $\mathrm{LGM}_{\mathrm{FIS} 50}$ & LGM & LGM & $50 \%$ LGM & LGM & LGM & 12 years \\
\hline $\mathrm{LGM}_{\mathrm{FIS} 150}$ & LGM & LGM & $150 \%$ LGM & LGM & LGM & 12 years \\
\hline LGM $_{\text {ALPSLESS }}$ & LGM & LGM & LGM & reduced LGM & LGM & 21 years \\
\hline
\end{tabular}



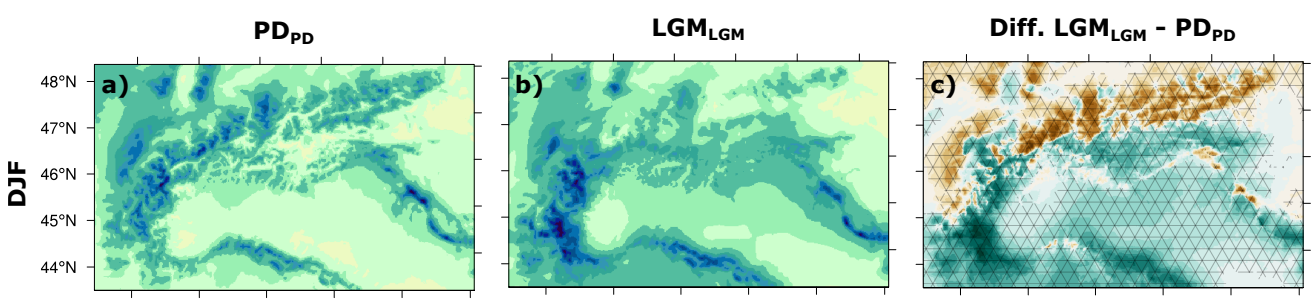

Diff. MIS4 ${ }_{L G M}-$ LGM $_{L G M}$
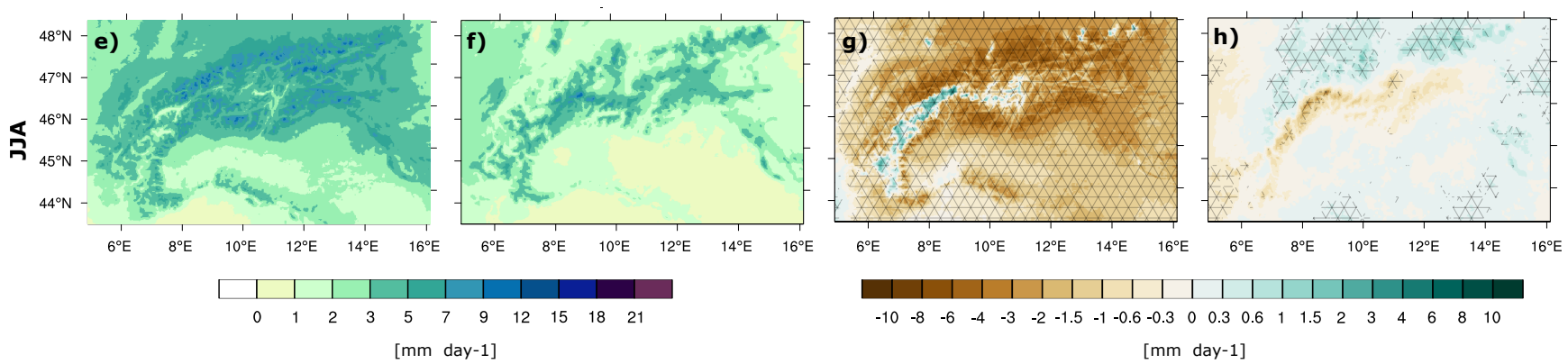

Figure 3. Climatological mean values of daily precipitation intensity over the Alps for (a, b, c and d) winter (DJF) and (e, f, g, and h) summer (JJA): (a, e) the mean PD precipitation, (b, f) the mean LGM precipitation, (c, g) the difference between LGM and PD and (d, h) the difference between MIS4 and LGM. Crosshatched areas represent statistically significant differences with a significance level of 0.05 (using a two-tailed bootstrapping technique). 
https://doi.org/10.5194/cp-2021-67

Preprint. Discussion started: 21 June 2021

(c) Author(s) 2021. CC BY 4.0 License.

(c) (i)

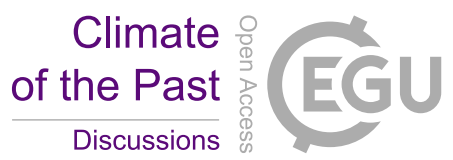

\section{Site A : North-Western Region}

DJF

a)

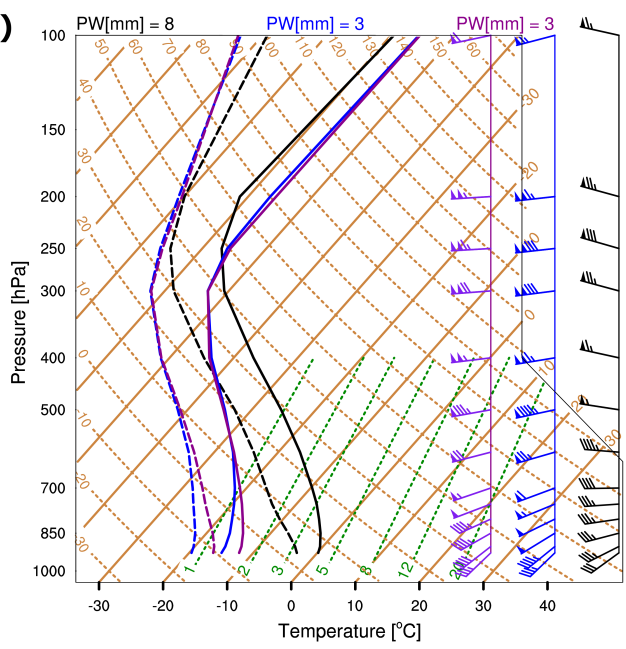

JJA

b)

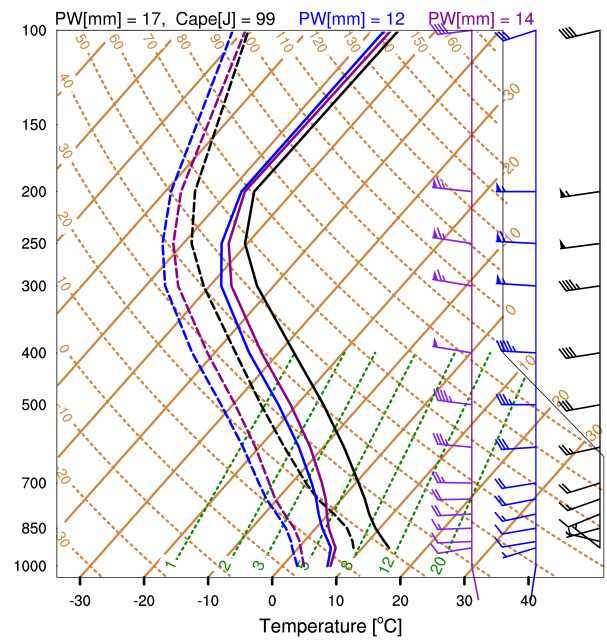

Site B : Central-Southern Region

DJF

c)

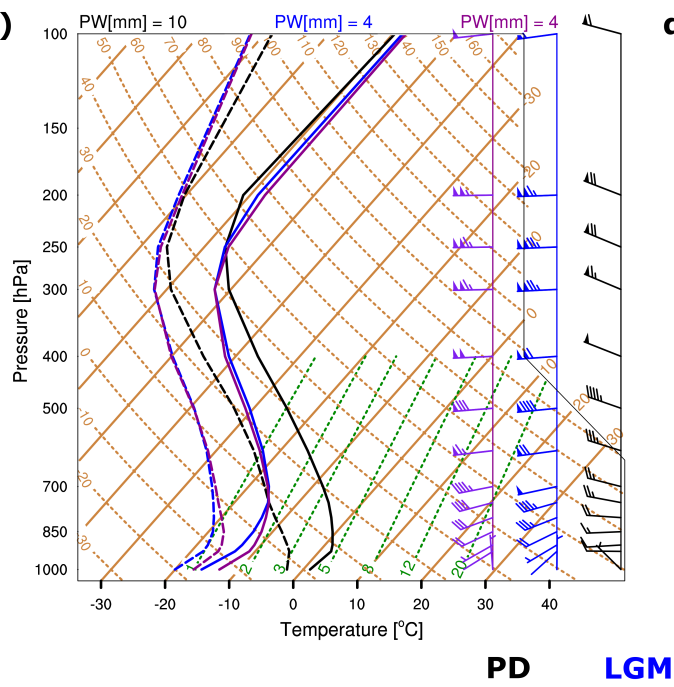

JJA

d)

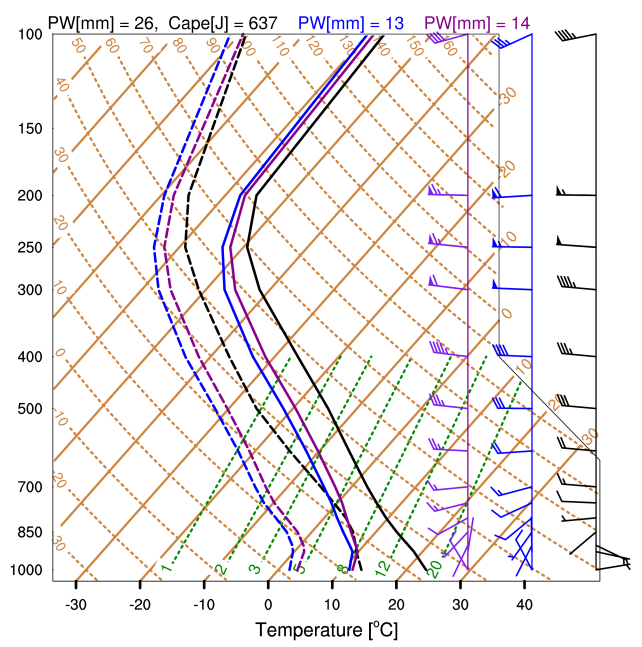

MIS4 $_{\text {LGM }}$

Figure 4. Skew-T diagram for site A (north-western region; a and b) and site B (central-southern region; c and d). Sites' locations are shown in Fig. 2. (a and c) represent climatological vertical profiles for DJF and (b and d) for JJA. PD climate is illustrated by black, LGM climate by blue and MIS4 $4_{\text {LGM }}$ climate by purple lines. Skewed straight dashed green lines represent isohumes labelled on the bottom of the diagram. The mixing ratio increases to the right at a constant pressure level. Solid brown lines are isotherms. Dry adiabatic lines (lines of equal potential temperature $\theta$ ) are slightly curved dashed brown lines. In the wind bars, the triangle, line and half-size line represent 50, 10 , $5 \mathrm{~km} \mathrm{~h}^{-1}$, respectively. Furthermore vertically integrated precipitable water (PW) and CAPE are given at the top of each panel. Note that CAPE is only displayed if it is different from zero. Please see Sect. 3 for a in-detail description of the Skew-T diagram. 

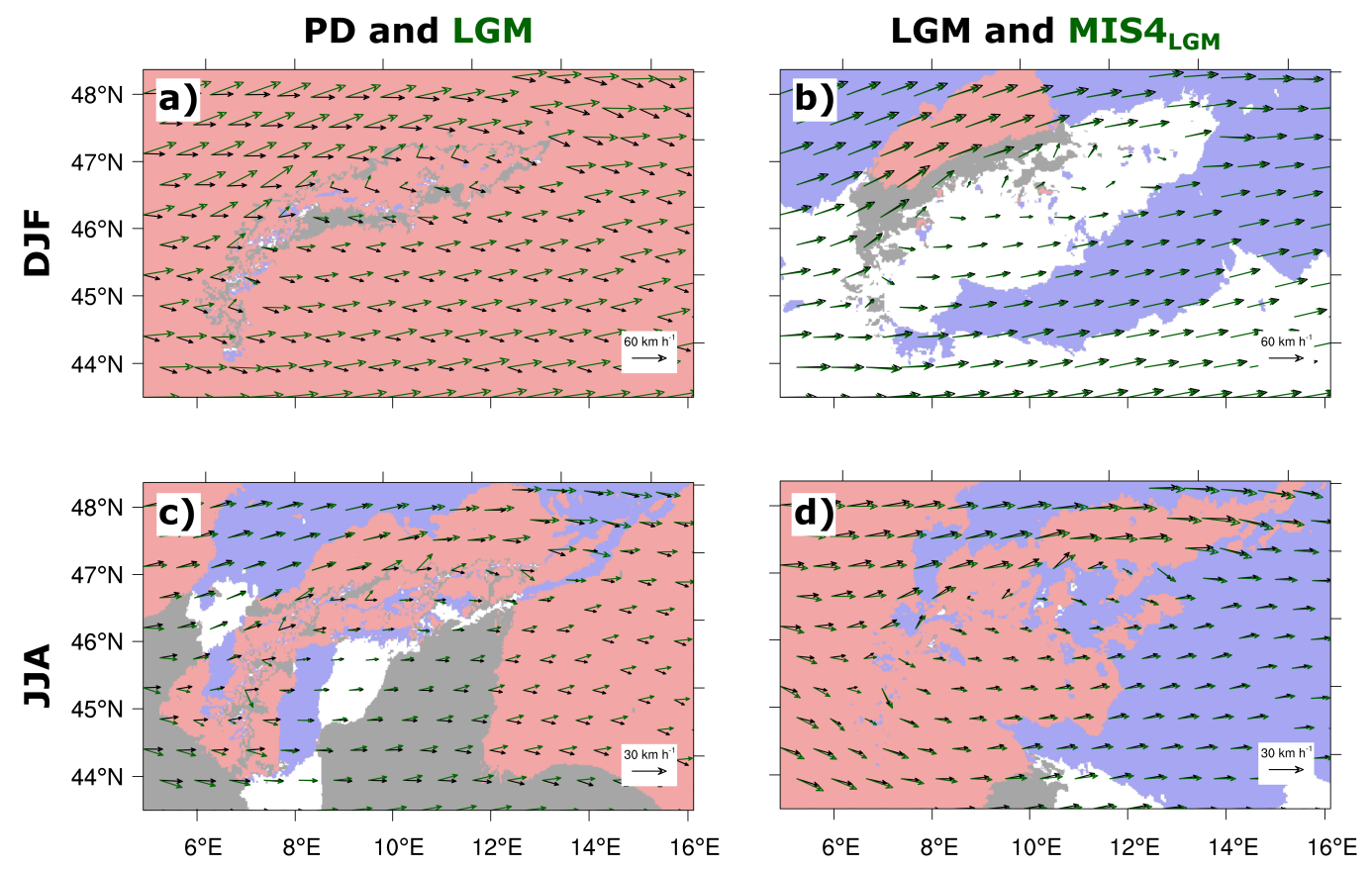

\section{Significant (0.05) U V U and V}

Figure 5. Climatological mean wind vectors over the Alps for (a and b) DJF and (c and d) JJA: (a and c) black and green wind vectors correspond to PD and LGM, respectively, (b and d) black and green wind vectors correspond to LGM and MIS4, respectively. Red shading illustrates statistically significant differences in zonal (U) and meridional (V) wind components with a significance level of 0.05 (two-tailed bootstrapping technique), blue and grey shading indicate significance either in the $\mathrm{U}$ or $\mathrm{V}$ wind component, respectively. Please note that the reference wind vectors differ for DJF and JJA. 

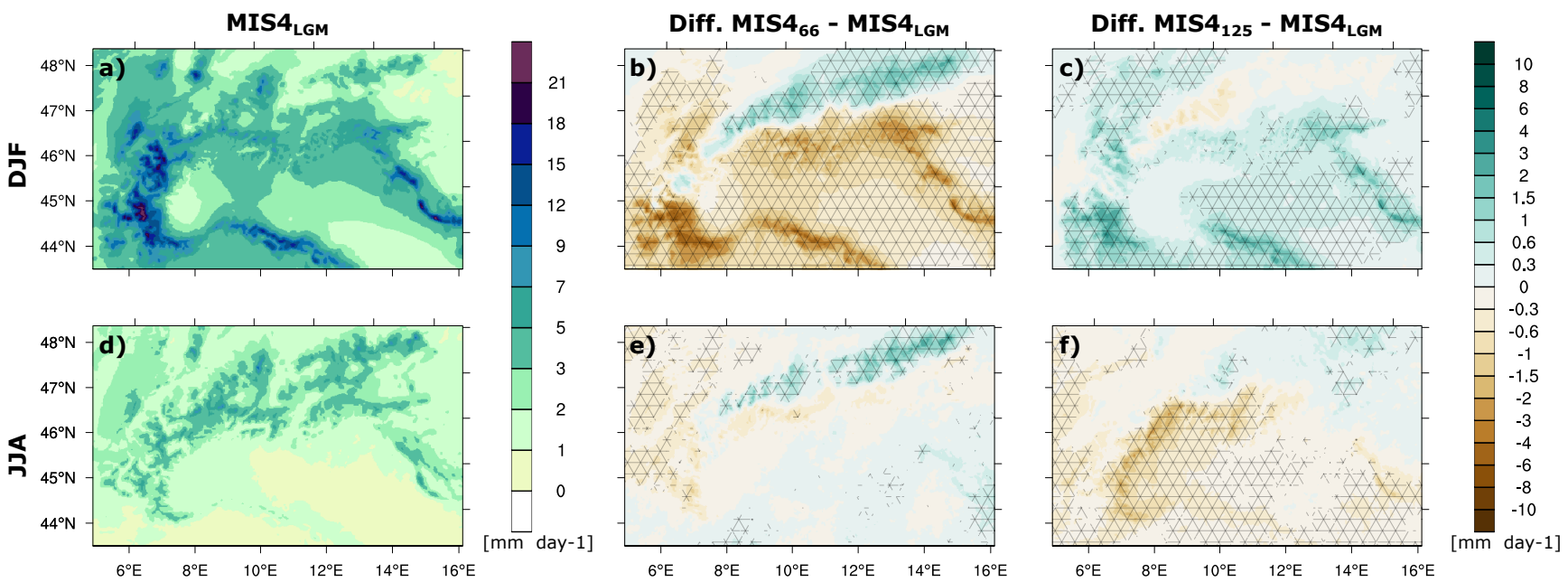

Figure 6. Climatological mean values of daily precipitation intensity over the Alps. (a) represents MIS4 $4_{\text {LGM }}$ precipitation for DJF, (b) the differences between MIS4 $4_{\mathrm{LGM} 66}$ and MIS4 $4_{\mathrm{LGM}}$, (c) as (b) but between MIS4 $4_{\mathrm{LGM} 125}$ and MIS4 $4_{\mathrm{LGM}}$. (d), (e) and (f) as (a), (b) and (c) but for JJA. Crosshatched areas indicate statistically significant differences at a significance level of 0.05 (using a two-tailed bootstrapping technique). 


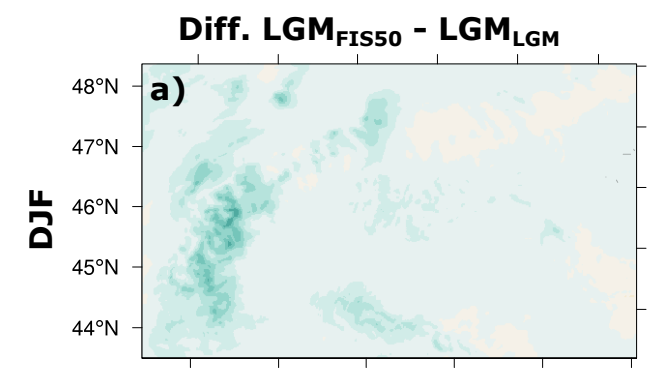

Diff. LGM FIS150 $_{\text {- LGM }}$ LGM
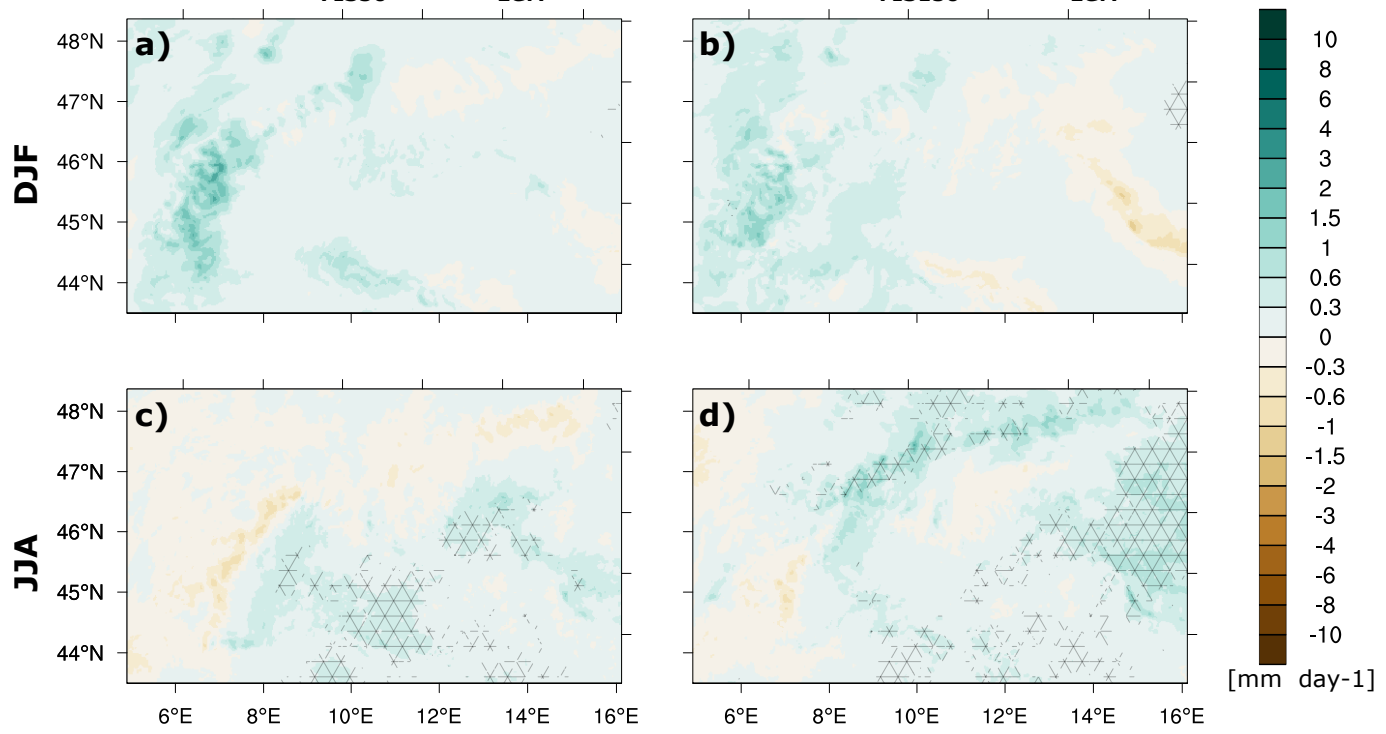

Figure 7. Differences in climatological mean values of daily precipitation intensity over the Alps for (a and b) winter (DJF) and (c and d) summer (JJA): (a and c) LGM FIS50 minus LGM $_{\mathrm{LGM}}$ and (b and d) LGM FIS150 minus LGM $_{\mathrm{LGM}}$. Crosshatched areas indicate statistically significant differences at a significance level of 0.05 (using a two-tailed bootstrapping technique). 


\section{Site A : North-Western Region}
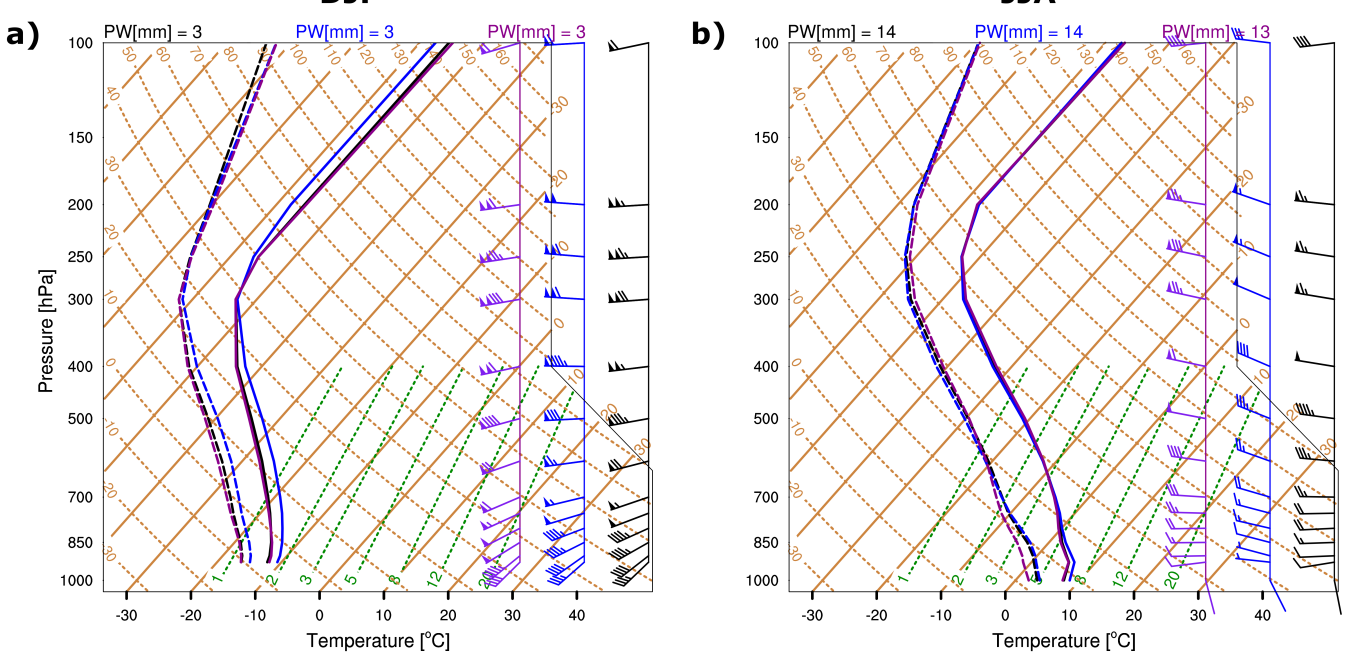

Site B : Central-Southern Region

DJF

c)

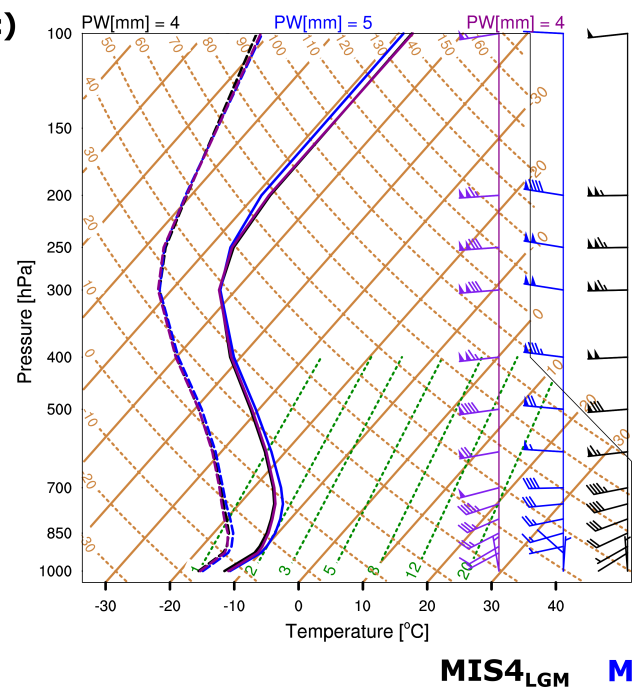

d)

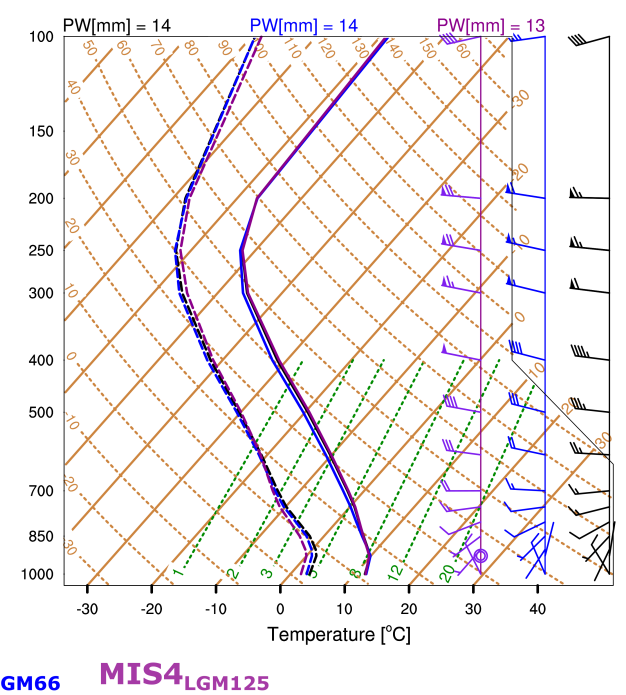

Figure 8. As Fig. 4, but for MIS4 $4_{\text {LG100 }}$ (black), MIS4 $4_{\text {LGM66 }}$ (blue), and MIS4 $4_{\text {LG125 }}$ (purple). 

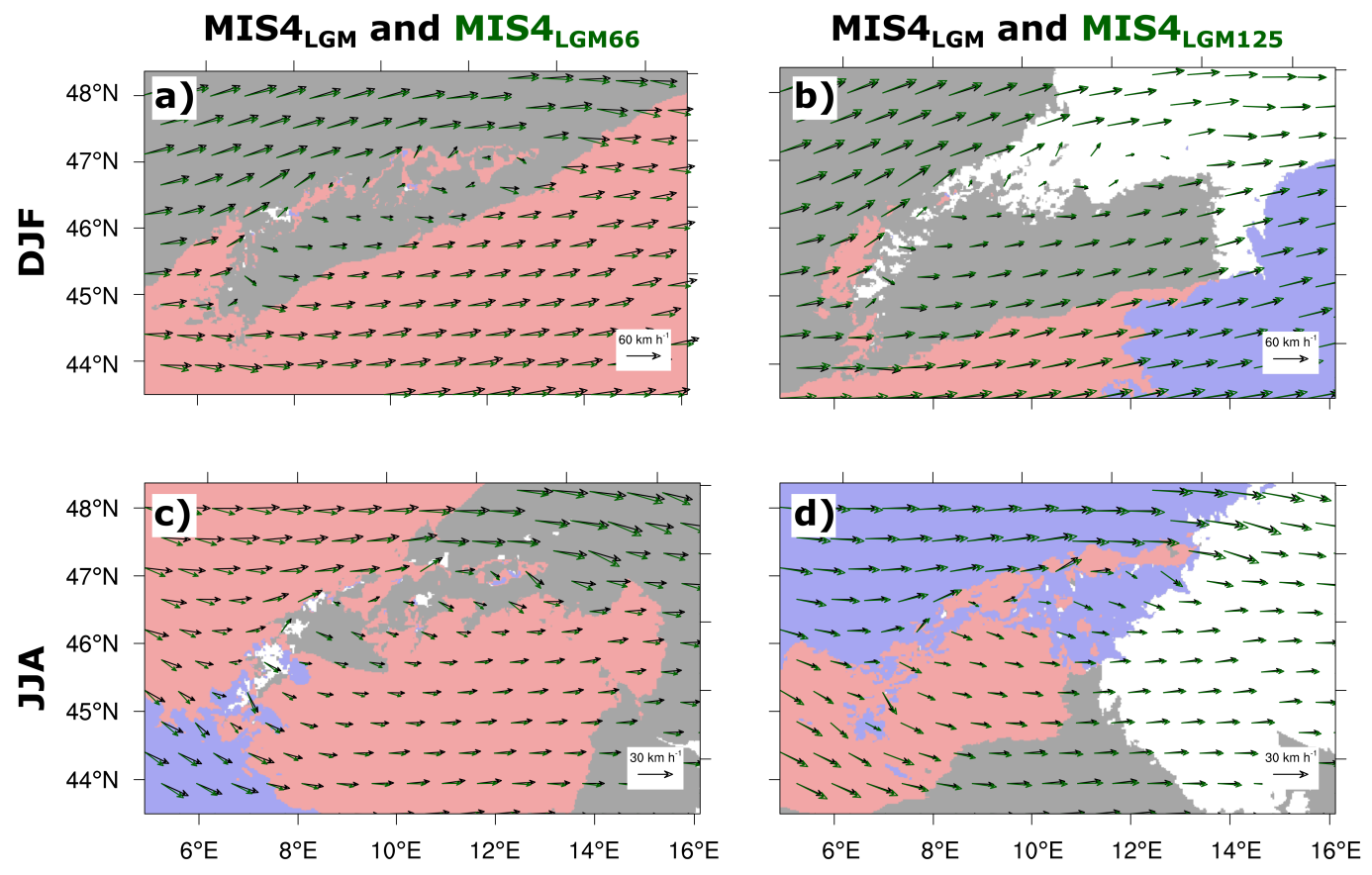

\section{Significant (0.05) U V U and V}

Figure 9. Climatological mean wind vectors over the Alps. (a) represents wind vectors for DJF, black and green vectors correspond to MIS4 $_{\text {LGM }}$ and MIS4 $4_{\text {LGM66 }}$, respectively, (b) as (a) but green vectors to MIS4 $4_{\text {LM125 }}$ (c) and (d) as (a) and (b) but for JJA. Red shading indicates statistically significant differences in zonal (U) and meridional (V) wind components at a significance level of 0.05 (two-tailed bootstrapping technique), blue and grey shading as the red one but only in $\mathrm{U}$ and $\mathrm{V}$ wind components, respectively. Please note that the reference wind vectors differ for DJF and JJA. 
https://doi.org/10.5194/cp-2021-67

Preprint. Discussion started: 21 June 2021

(c) Author(s) 2021. CC BY 4.0 License.

(c) (i)
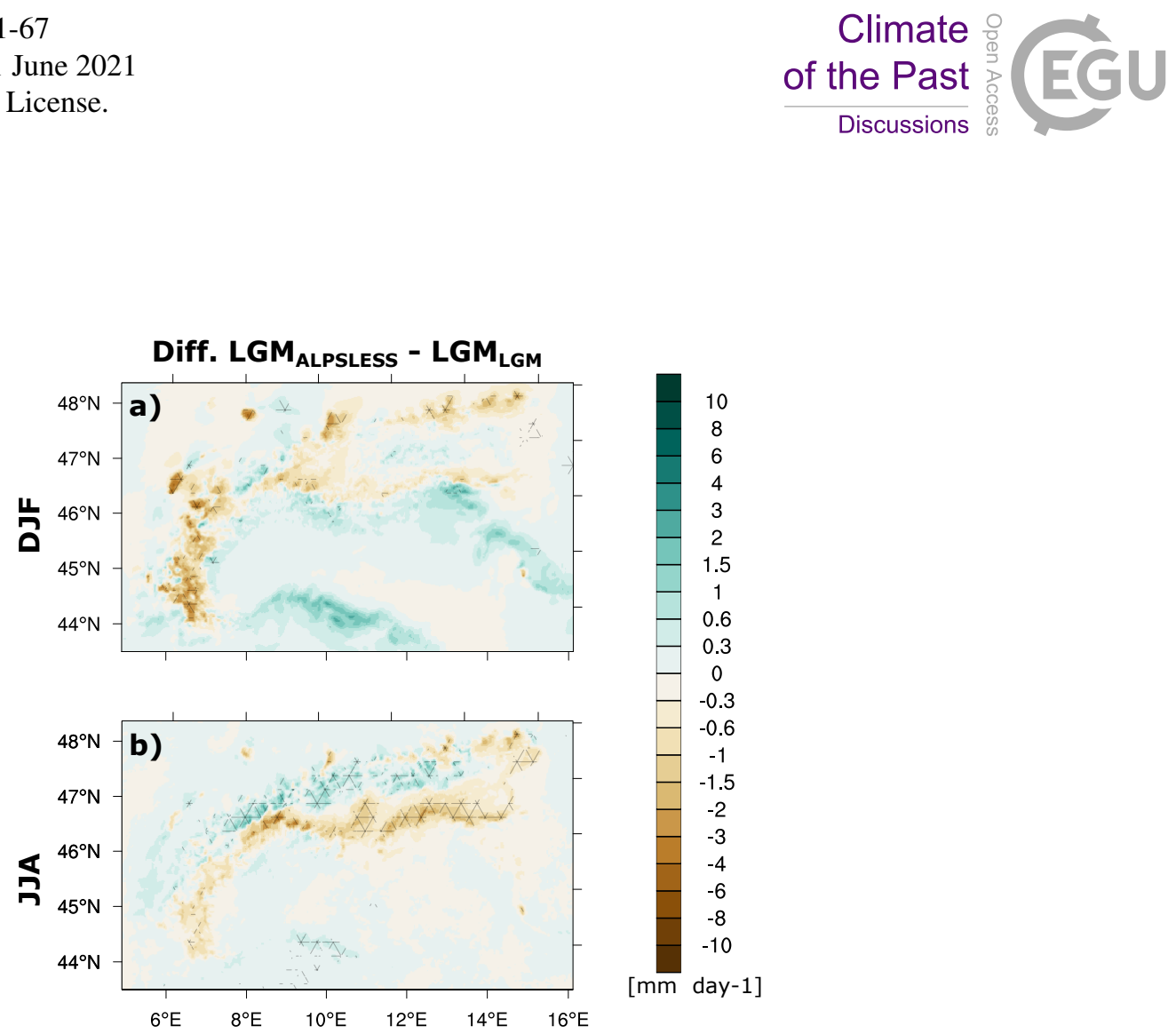

Figure 10. Differences in climatological mean values of daily precipitation intensity over the Alps between LGM ALPSLESS $_{\text {and LGM }}$ LGM for (a) winter (DJF) and (b) summer (JJA). Crosshatched areas indicate statistically significant differences at a significance level of 0.05 (using a two-tailed bootstrapping technique). 
https://doi.org/10.5194/cp-2021-67

Preprint. Discussion started: 21 June 2021

(c) Author(s) 2021. CC BY 4.0 License.

(c) (i)
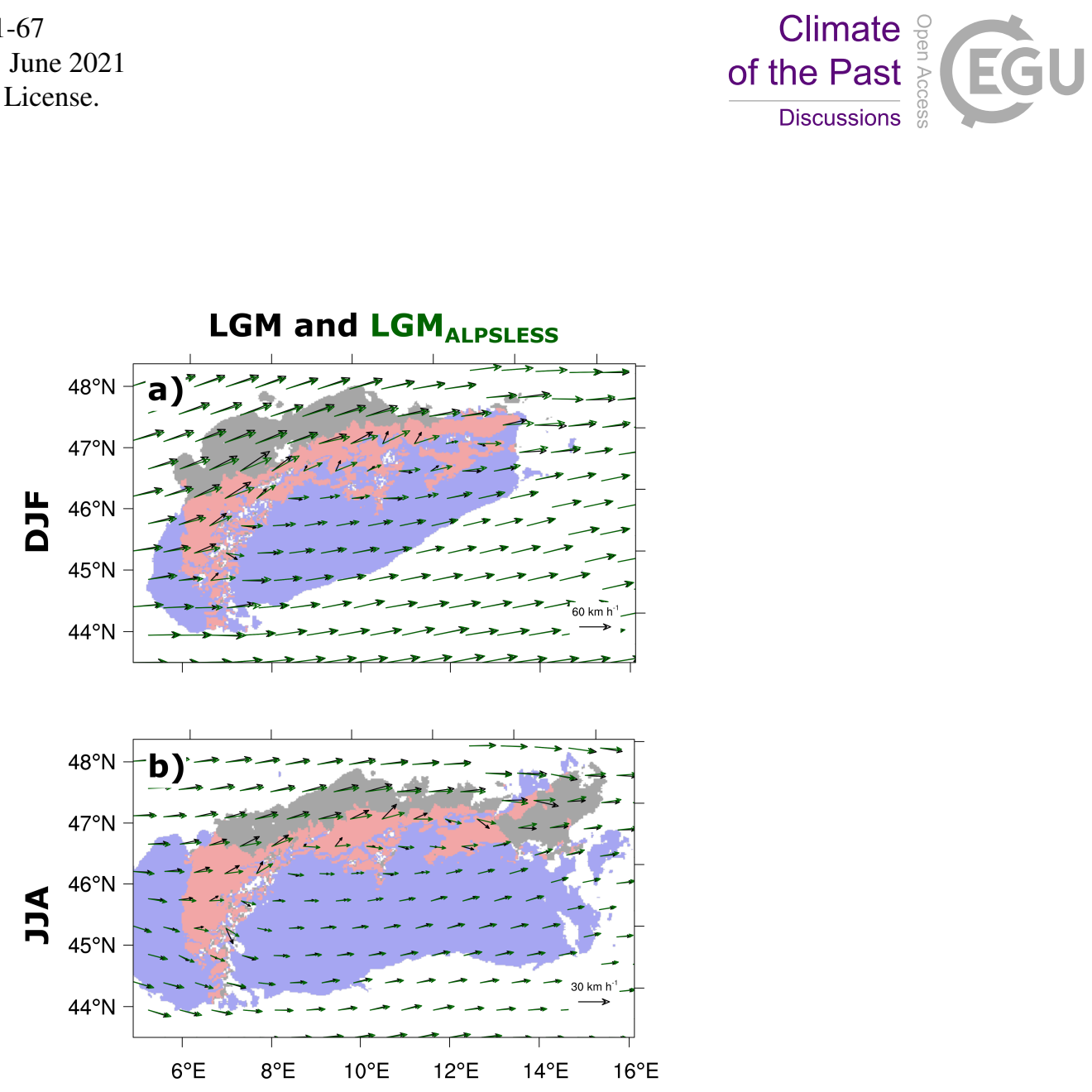

Significant (0.05) U V U and V

Figure 11. Climatological mean wind vectors over the Alps. (a) represents wind vectors for DJF, black and green vectors correspond to LGM $_{\text {LGM }}$ and LGM ALPSLESS, (b) as (a) but for JJA. Red shading indicates statistically significant differences in zonal (U) and meridional (V) wind components at a significance level of 0.05 (two-tailed bootstrapping technique), blue and grey shading as the red one but only in $\mathrm{U}$ and $\mathrm{V}$ wind components, respectively. Please note that the reference wind vectors differ for DJF and JJA. 